К. В. Вершинин

Институт российской истории РАН

(Россия, Москва)

versh-kv@yandex.ru

\title{
ДРЕВНЕРУССКОЕ ТОЛКОВАНИЕ НА ИРМОСЫ КРЕЩЕНИЯ ${ }^{1}$
}

Статья содержит исследование и публикацию экзегетического послания анонимного духовного лица древнерусскому князю, известного в единственном списке 30-х гг. XVI в. под заглавием «Ермоси на Крещение Господа нашего Исуса Христа». Памятник представляет собой комментарий к ирмосам второго богоявленского канона (Иоанна Дамаскина). Особенности содержания толкований указывают на знакомство автора этого сочинения с греческим прототипом ирмосов. Автор послания обращается, в частности, к учению о трех частях души и цитирует толкования Никиты Ираклийского на слова Григория Богослова, что делает памятник важным свидетельством рецепции перевода этого сочинения на Руси. Анализ текста позволяет сделать вывод о раннем - вероятно, домонгольском, - происхождении памятника. Высказывается предположение, что послание было написано Кириллом Туровским для князя Андрея Юрьевича Боголюбского.

Ключевые слова: Ирмологий, Григорий Богослов, Никита Ираклийский, Кирилл Туровский, древнерусская литература, славянская переводная литература

Памятник, предлагаемый вниманию читателей, до сих пор не исследовался и не издавался. Известен единственный его список в рукописи 30-х гг. XVI в. РГБ, Во-

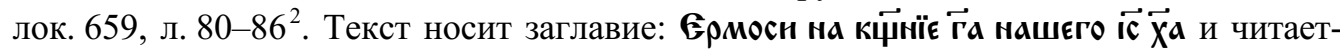
ся в первой части сборника-конволюта (л. 3-99), переписанной одной рукой на бумаге с филигранью, больше в манускрипте не встречающейся ${ }^{3}$. Кроме «Ирмосов»,

${ }^{1}$ Выражаем сердечную благодарность А. М. Молдовану за ценные советы и замечания, высказанные при подготовке нашей статьи.

${ }^{2}$ О нем см., например: [Клосс 1980: 82-83].

${ }^{3}$ Цветок под короной, близкий к Брике 6414 (1532 г.) 
здесь помещены «Азбука о воскресении Христове» ${ }^{4}$ и толкования на богослужебные каноны ${ }^{5}$.

Толкования на каноны (преимущественно на двунадесятые праздники), встречающиеся в древнерусских рукописях, редко привлекали внимание исследователей. Н. К. Никольский между прочим замечал, что, «по-видимому, эти толкования... составляли собою... одну семью» [Никольский 1892: 22]. В описи книг КириллоБелозерского монастыря, составленной в XVI в., «каноны толковыя» фигурируют как название особой рукописи, но такое название местные книжники прилагали к сборнику первой четверти XV в. РНБ, Кир.-Бел. 19/1096, где читаются и многие другие тексты [Никольский 1897: 269-270] ${ }^{6}$. Однако порой толковые каноны, действительно, переписывались в виде отдельной книги: укажем, к примеру, рукописи РГБ, Унд. 546, 1624 г. (описание см.: [Ундольский 1870: 404-405]) и РГБ, Овчин. 215, XVII в. Не задаваясь целью осветить всю археографию памятника, заметим, что набор толкуемых канонов в рукописях может различаться ${ }^{7}$. Никольский относил толковые каноны к числу книжных раритетов, но на самом деле они еще в XVIII в. были хорошо известны старообрядцам: их чтение на трапезе предписывалось уставом Выговской пустыни [Юхименко 2013: 91]. Интерес к памятнику сохранялся и позднее: так, список толковых канонов - вероятно, позднейший из существующих - был изготовлен И. Г. Блиновым для П. А. Овчинникова в 1900 г. [Аксенова 2011: 153].

Недавно толковые каноны стали объектом внимания С. Ю. Темчина, который выявил «до 40» их списков различной степени полноты [Темчин 2017: 224]. Если Н. К. Никольский не сомневался, что памятник представляет собой «перевод из ка-

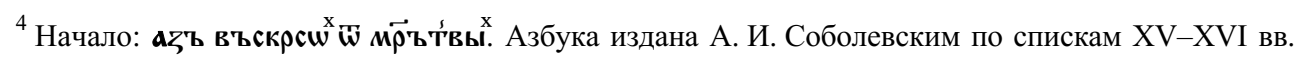
[Соболевский 1910: 30-33].

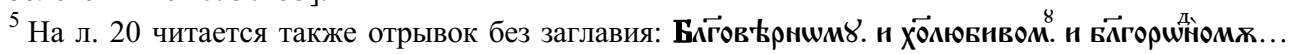
вєкнком૪ кн̈Sю нванУ васни́євнчю, который представляет собой выписку из формулярного извода послания Симона Чижа, будущего митрополита, с подстановкой имени великого князя (судя по датировке сборника, скорее Ивана III, чем Ивана IV). Ср. [Плигузов 2008: 255].

6 Это старший известный список толковых канонов, если не считать фрагментов в двух пергаменных рукописях конца XIV в., а именно: 1) сборнике ГИМ, Увар. 589-4을. л. 99-99об., где читаются выписки из толкований на каноны Пасхе и Великому Четвергу, на каком-то этапе восприня-

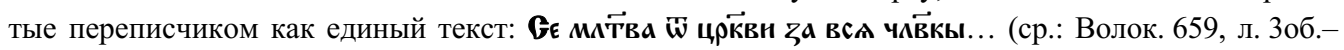
4; 91об.-92; 93); 2) Златой Цепи (1-го типа) РГБ, Тр. 11, л. 56-56об. (издание см.: [Крутова 2003: 93-94]), где полный текст толкования 2-го тропаря 7-й песни канона Великому Четвергу составля-

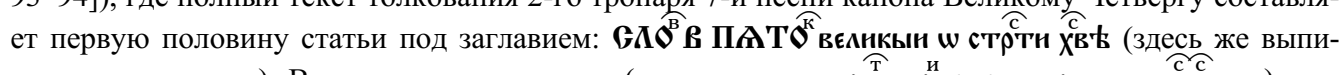

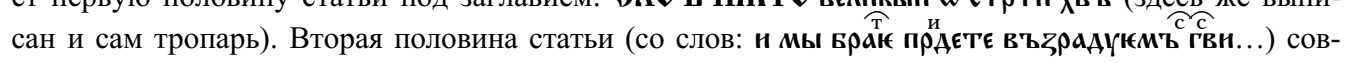
падает с окончанием слова Кирилла Туровского на Вознесение, ср.: [Еремин 1958: 343].

${ }^{7}$ Максимальное число канонов - десять - находим, например, в Овчин. 215: на Воздвижение Креста, Рождество (два), Крещение, Сретение, Вербную неделю, Великий четверг, Пасху, Преполовение и Пятидесятницу. 
кого-либо греческого автора» [Никольский 1892: 22], то С. Ю. Темчин находит в тексте восточнославянские черты ${ }^{8}$ и приводит веские доводы в пользу того, что перед нами оригинальное сочинение древнерусского экзегета. Из архаических южнославянизмов, не учтенных в работе исследователя, можно указать: нєгонъднами (Л. 34), кажненїа 'казНи' (л. 43об.), не могАнть (л. 56), в́ породЊ (Л. 79), ннотАжь 'постоянно’ (л. 79об.) 9 , шБмашїа 'миряне' (л. 97об.).

«Ирмосы на Крещение» помещены в сборнике Волок. 659 после канона Воздвижению. Во всех прочих известных списках толковых канонов этот текст отсутствует ${ }^{10}$. Как нам представляется, «Ирмосы» по своему происхождению не связаны с толковыми канонами. Они относятся к различным литературным жанрам: если толковые каноны оформлены по принципу своего рода катен, где приводятся и последовательно толкуются все ирмосы и тропари канонов, то в «Ирмосах на Крещение» перед нами послание, адресованное, как следует из текста, некоему «князю», «христолюбцу». Оно представляет собой комментарий к ирмосам второго богоявленского канона (Иоанна Дамаскина). Автор не выписывает все ирмосы целиком, а последовательно разбирает их по частям, органически вплетая эти части в свое послание. Инородность «Ирмосов на Крещение» по отношению к их окружению в данной рукописи можно видеть и в том, что все комментируемые в «Ирмосах» тексты уже разобраны в этой рукописи в толковом каноне на Крещение (л. 29-41об.). Очевидно, что в окружение толковых канонов наш памятник попал по принципу аналогии.

Яркой особенностью толковых «Ирмосов на Крещение» является их эпистолярная форма, хотя памятник не содержит сведений об авторе и адресате. Элементами этой формы являются обращения автора к адресату: кнажє $(6 \times)$, Братє $(1 \times)$, старьншнно $(1 \times)$, ХртТкюбчє $(1 \times)$ и использование автором двойственного числа для риторического объединения себя с адресатом (см. ниже). Заключается послание

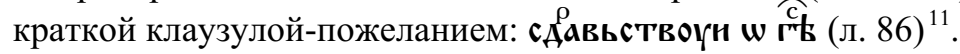

Содержание толковых «Ирмосов на Крещение» представляет двоякий интерес. С одной стороны, памятник лежит в русле традиции увещевательных пастырских посланий: предметом, связующим толкования отдельных ирмосов, является наставление адресата в христианском благочестии, призыв к «попалению» «сластей мира сего». С другой стороны, «Ирмосы» представляют собой ценное дополнение к кор-

\footnotetext{
${ }^{8}$ Формы отчеств (снраховнчємъ л. 31 и др.), употребление слова вьрста в значении 'мера длины' (л. 28).

${ }^{9}$ Слово известно лишь по Шестодневу Иоанна экзарха Болгарского [СлРЯ XI-XVII 6: 244].

${ }^{10}$ Благодарим С. Ю. Темчина за это указание.

11 Эта формула широко известна в греческой письменности (ближайший доступный славянским книжникам пример - в послании Иоанна Раифского Иоанну Синайскому, помещаемом в списках «Лествицы»). Примеры ее употребления на Руси, начиная с XV в., многочисленны; наиболее ранний из нам известных относится к концу XIV — началу XV в. и читается в послании, которое Г. М. Прохоров атрибутирует Епифанию Премудрому [Прохоров 1987: 90].
} 
пусу древнерусской экзегетики - жанра не самого популярного в оригинальной восточнославянской книжности.

Памятник был создан на Руси, что следует из слов самого автора: мы во ролсь. тако поємъ... (Волок. 659, л. 84об.). Сколь ни мал авторский текст (цитаты из Ирмология и Священного Писания здесь не показательны, так как сочинитель послания мог пользоваться древними манускриптами), данные правописания и языка свидетельствуют, что послание имеет весьма древнее происхождение. Орфография рукописи в границах рассматриваемого текста представляет собой классический случай, когда наряду с особенностями, объясняющимися вторым южнославянским влиянием (спорадическое смешение ъ и ь, ї перед гласными, написания типа таd; один случай употребления буквы ж: Р. мн. забъ, л. 82), в рукописи можно наблюдать древнерусские черты - oy в начале слов: oyroy (л. 80), oycтнн' (л. 82); полногласие: молотомъ (л. 82); написания с ж в соответствии с $* d j$ и ч на месте *tj:

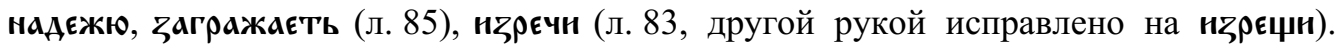
В некоторых написаниях можно усмотреть отражение бытовой системы письма,

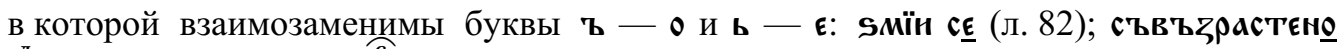

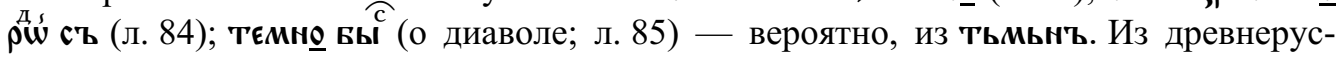
ских морфологических черт можно отметить форму действительного причастия настоящего времени рєка, представленную пятью примерами (в том числе дважды в написании рњка).

В тексте употребляется двойственное число, в том числе в конструкциях в императивной формой БољАн: БоУАн мама потопнтн то трнчастное (л. 80об.) и с сослагательным наклонением: Аа ащє выховћ то троє нсправнан. то трнстаты

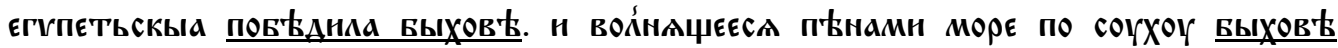
прошиа (л. 81). Единственная ошибка в согласовании (исправнхн вместо нсправнма) может быть отнесена на счет переписчика. Полноударные местоимения присутствуют только в тех позициях, где энклитические формы невозможны, например:

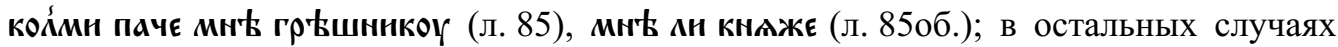
читаются только энклитики (мн 2х; ма 1 ; Д. ны $2 \times$; В. ны 1 ; тн $4 \times$, не считая библейских цитат). К архаизмам следует причислить формы причастий: шчнщьшєсА (л. 83), прєложь (л. 84об.). Из других особенностей небезынтересно отметить фразу

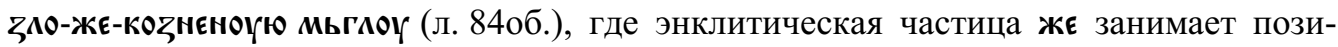
цию между корнями композита ${ }^{12}$.

Обращают на себя внимание редкие лексемы: красогласованїа (л. 82об.) и многобожьствїа (л. 84) - обе известны по первому славянскому переводу хроники Георгия Амартола [СлДРЯ XI-XIV 4: 286; 5: 59], вторая - также по «Слову о законе и благодати» Илариона (в форме ед. род. многовожьства, см.: [Молдован 1984:

12 Вероятно, zм0 в этом обособленном положении осознается как проклитика и, таким образом, сочетание зАо жє следует оценить - пользуясь терминологией А. А. Зализняка - как проклитикоэнклитический комплекс [Зализняк 2008: 72-74]. 
79, 110, 139]) и по ноябрьской минее 1097 г. [СлРЯ XI-XVII 9: $195^{13}$ ]; стогАоложїє (л. 84об.) - зафиксировано в переводе толкований Никиты Ираклийского на слова Григория Богослова (стү/Аоложнкмъ: ГИМ, Син. 43, л. 10a) ${ }^{14}$. Шесть раз в тексте употреблено выражение а рєкоу 'то есть', незнакомое южнославянской книжности, но хорошо известное по древнерусским толковым переводам XII в. [Алексеев 1988: 164; Бабицкая 1995: 632]. Уникален цитируемый в послании перевод стиха Притч.

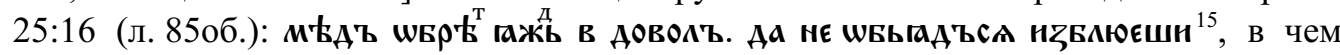
можно видеть еще одну особенность, связывающую текст с древнерусской традицией, где встречаются ветхозаветные цитаты (в частности, из Притчей) в особых редакциях, расходящихся с текстами полных четьих переводов ${ }^{16}$. В словах: «прєжє страстноє» газычьскаА црјкы єже єсмы мы (Л. 85) видно восприятие крещения Руси как относительно недавнего события. Совокупность этих данных позволяет с высокой вероятностью относить памятник к домонгольскому времени.

Из содержания толкований следует, что автор имел возможность сопоставить текст ирмосов с греческим оригиналом. Об этом свидетельствует его замечание по поводу интерпретации ирмоса 7-й песни 2-го гласа, который читается так: Испамн ВОАОЮ. ЗМНЕВЫА ГААВЫ. ПЕЩЬНААГО ВЫСОКААГО ПААМЕНЕ. ОУНОША НМОУЧН БААГО-

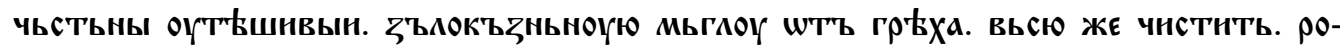
сою доуховьною (Воскр. 28-перг., кон. ХІІ в., л. 52об.). Автор дает к этому ирмосу следующий комментарий: н «оү'т"'шнвь» нмъ пхамєнь. н в «росоү» прекожь мы во

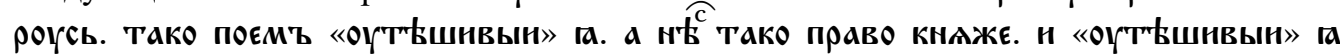
(л. 84об.). Смысл комментария следует понимать следующим образом: «н оүт"女шнвь» - то есть погасив им пламя, и превратив его в «росоу» — ибо мы, русь, так поем и понимаем: «оү'тьшнвын» их [т. е. юношей]. А это, княже, неправильно». Такое понимание, действительно, следует из греческого текста: "Е $\varphi \lambda \varepsilon \xi \varepsilon \dot{\rho} \varepsilon i ́ \theta \rho \tau \tilde{\omega} v$

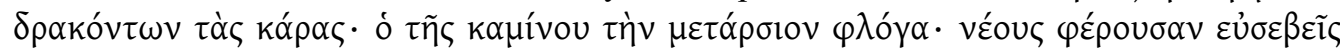

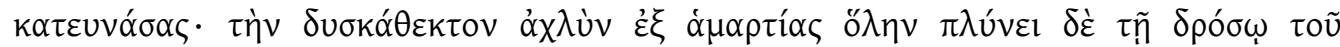

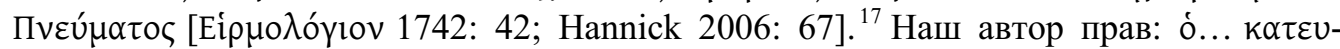

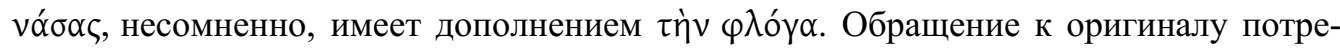
бовалось автору, очевидно, потому, что уже ко времени написания толкования сла-

13 Здесь слово под титлом раскрыто как многовожествнє.

${ }^{14}$ В словаре зафиксировано по другому списку того же памятника в варианте стүАоможьє [СлДРЯ XI-XVII 11: 667].

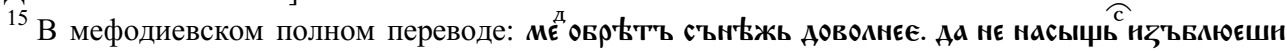
(РГБ, Волок. 13, л. 123об.).

${ }^{16}$ Например, в Мериле Праведном стих Притч. 17:20 читается как мскомуднвъ газыкомь впадакть въ zлW (Тр. 15, Л. 11об.), где мскокуАнвъ (из москологАнвъ) - производное от моско-

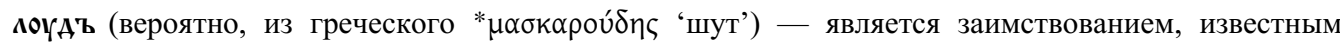
только восточнославянским памятникам [Пичхадзе 2011: 94].

17 Перевод: «Сжег струею головы драконов успокоивший высокое пламя печи, охватившее благочестивых юношей; неукротимый туман греха смывает росою Духа». 
вянский перевод ирмоса 7-й песни 2-го гласа представлял для многих синтаксическую загадку. Косвенное подтверждение этому можно видеть в ошибке, вкравшейся

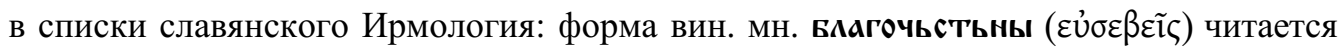
только в древнейших манускриптах XII в. новгородского происхождения - ГИМ, Воскр. 28-перг. и РГАДА, Син. тип. 150 [Hannick 2006: 261] ${ }^{18}$. Послание неизвестному князю апеллирует (в парафразе: Б्रгочтнвыа) к этому исконному чтению. Во всех прочих рукописных ирмологиях, привлеченных к изданию К. Ханником, фигурирует явно ошибочное влагочьстьно ${ }^{19}$, появившееся, по-видимому, в результате неверного осмысления темного места одним из переписчиков ${ }^{20}$.

В другом случае автор прямо сообщает о своем обращении к греческому тексту, чтобы привести более точный перевод трудного места ирмоса 4-й песни: нашнмъ

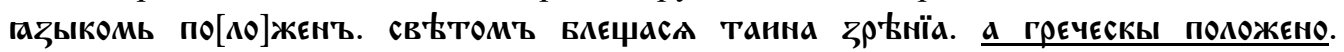

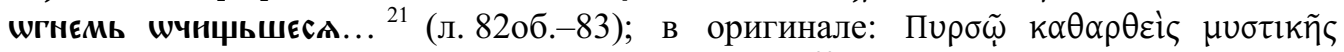

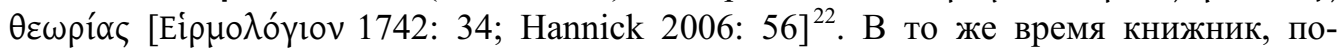
видимому, не сверял последовательно славянский текст ирмосов с греческим оригиналом. В словах ирмоса 3-й песни єже $\mathbf{\omega}^{23}$ на внд всте Аарованїє (82об.) он не заме-

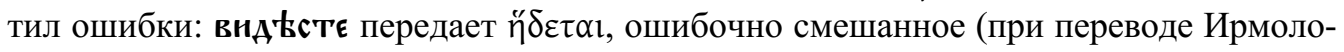

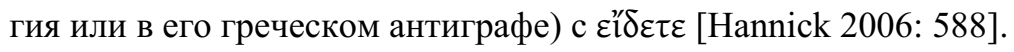

Что касается книжных источников, то один из них называется автором - это творения Григория Богослова, а вернее, сборник 16 слов великого каппадокийца, снабженный комментариями Никиты Ираклийского в переводе Slav. 1 по терминологии А. М. Бруни [Бруни 2013: 34] ${ }^{24}$. Считается, что этот славянский перевод толкований был выполнен восточнославянскими книжниками [Горский, Невоструев 1859: 85-86; Пичхадзе 2011: 33-34; Молдован 2016] ${ }^{25}$, в отличие от переведенных у южных славян гомилий св. Григория.

18 Здесь же указано чтение влагочєстнвы во львовском печатном Ирмологионе 1700 г. Оно могло, однако, появиться благодаря сверке текста с греческим оригиналом при подготовке этого издания.

${ }^{19}$ Следует отметить, что это чтение без должных оснований включено немецким ученым в критическую реконструкцию текста [Hannick 2006: 66].

${ }^{20}$ Неизвестно, знаком ли был с этим исправлением автор экзегетического послания, но оно, кажется, вытекает из той самой (неверной) трактовки ирмоса, которая имеется в виду книжником: эпитет вцагочьстьно звучит натянуто применительно к «утешению» пламени, но вполне уместен, если речь идет об успокоении отроков.

${ }^{21}$ Возможно, в конце ошибка (вместо шчнщьсл), если только не пример несогласованного причастия.

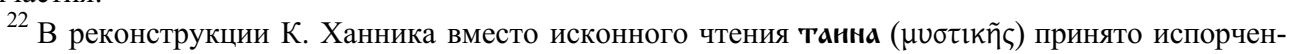
ное танно [Hannick 2006: 57].

23 Ошибка в рукописи: должно быть w.

24 Обзор рукописей см.: [Бруни 2004: 119-191].

25 Малоизученная версия Slav. 2 представляет собой другой перевод или, что также не исключено, редакцию первого перевода на южнославянской почве [Горский, Невоструев 1859: 92-98; Бруни 2013: 41]. 
Одним из древнейших славянских сочинений, в которых исследователями были опознаны цитаты из перевода толкований Никиты, является датируемое XII в. Слово Кирилла Туровского на Новую неделю [Виноградов 1915: 114-115; см. также Буланин 1991: 140-141; Понырко 2008: 134] ${ }^{26}$. А. М. Бруни, правда, считает, что знакомство русского епископа с толкованиями на слова св. Григория «невозможно доказать» [Бруни 2013: 37]. Это замечание вызывает недоумение. На самом деле наблюдения В. П. Виноградова не только остаются в силе, но могут быть дополнены по меньшей мере еще одним сопоставлением:

\begin{tabular}{|c|c|}
\hline Кирилл Туровский & Никита Ираклийский \\
\hline И пьтица бо, рече пророк, обрбте & ТНМЖE HE ТОКМО НЁСа \\
\hline гнђздо себъ олтаря твоя — и свою & 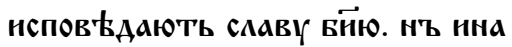 \\
\hline каяждо поющи пъснь, славять Бо- & 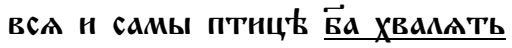 \\
\hline га гласы немолчьными [Ере & ГАаСЫ НЕМОАЧЬНЫМН \\
\hline 1957: 417] & (РГБ, Тр. 8, л. 148) \\
\hline
\end{tabular}

Приведенный в таблице текст читается в большинстве списков Слова на Новую неделю, включая древнейший - РНБ, F.п.1.39, ХІІІ в. [Еремин 1955: 351] ${ }^{27}$. Всюду Кирилл Туровский пользуется комментариями ираклийского митрополита на 44 слово св. Григория (На неделю новую, на весну и на память мученика Маманта).

«Ирмосы на Крещение», подобно Слову Кирилла Туровского, содержат цитаты из сборника 16 слов Григория Богослова с толкованиями Никиты Ираклийского. Прежде всего, автором привлекается комментарий на вышеупомянутое 44 слово. Текст гомилии и толкования на нее в этой выписке переплетаются.

\begin{tabular}{|c|c|c|}
\hline «Ирмосы на Крещение» & й Бого & Никита Ираклийский \\
\hline 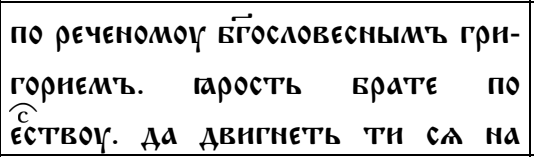 & 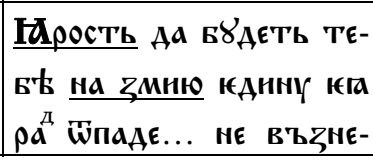 & 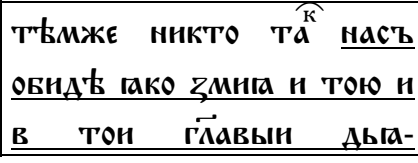 \\
\hline
\end{tabular}

${ }^{26}$ Обзор влияния слов св. Григория (как с толкованиями, так и без них) на славянскую письменность см. [Буланин 1991: 154-172]. В первые три века существования древнерусской книжности комментарии Никиты в славянском переводе отразились (помимо слова Кирилла Туровского) в послании митрополита Никифора Владимиру Мономаху [Горский, Невоструев 1859: 86; Молдован 2013: 213], а также, по-видимому, в Толковой Палее и Иудейском хронографе. Впрочем, наблюдения в отношении двух последних памятников пока предварительны [Буланин 2014: 464-465].

${ }^{27}$ Указанное место сильно отредактировано в рукописи конца XIV в. ГИМ, Увар. 589-4 ${ }^{\circ}$, цитата из толкования Никиты там оборвана: «Иже суть церковнии чини: епископи, игумени, попове, дьякони, дьяци, и свою каждо поюще пъснь, славят Господа» [Еремин 1957: 417]. Этот список взят за основу в издании [Сухомлинов 1858: 19-24]. 
SMÏЮ ТОК'МО. ННКТОЖЕ БО На ТА ТАКО НАВНАН БРА СВОКГО. Н СЕ

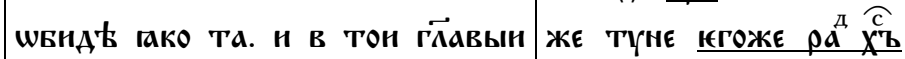

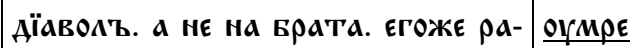

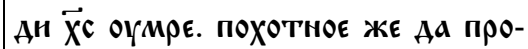
СТРЕТЬ ТН СА ВСЕ КЪ ЕАНHOMOY

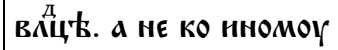

(Волок. 659, л. 80об.-81)

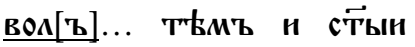
IAPOCTЬ АВНГNIT'Н ВENHTЬ по КстьствоY на 弓MHю... ПОХОТНОК ЖЕ НН КЪ КАННОМҮ ЖЕ ВРЕАНО. Н' К' БО्У BCE ПРОСТЕРЕТН

(РГБ, Тр. 8, л. 144)

Известна книжнику и 39-я гомилия св. Григория (На святые светы явлений Господних), на которую делается отсылка (без цитаты): многы сњтн Быша на родог

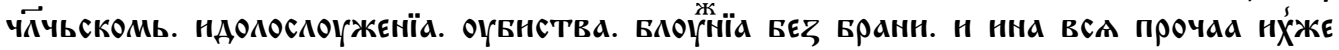

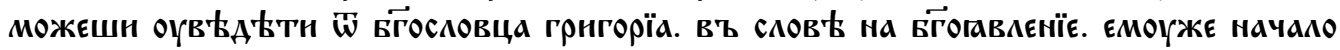
пакы мон іс. и пакы танна (л. 81об.) Имеется в виду знаменитое описание языческих культов, которым Григорий Богослов противопоставляет возвышенное таинство Крещения Христова. Пользовался наш автор и толкованием Никиты Ираклийского на упомянутую гомилию, как видно из следующего сопоставления:

\begin{tabular}{|c|c|c|}
\hline «Ирмосы на Крещение» & Григорий Богослов & Никита Ираклийский \\
\hline 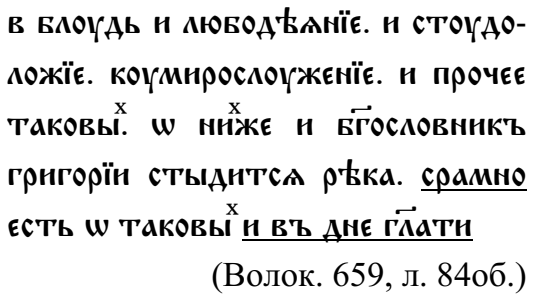 & 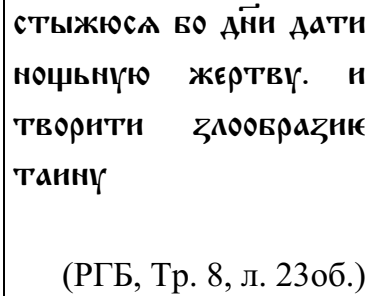 & 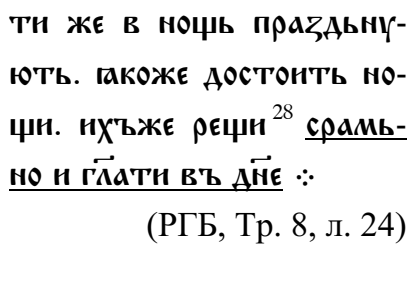 \\
\hline
\end{tabular}

Не удалось обнаружить точного соответствия еще одной цитате: пншєть Бо и

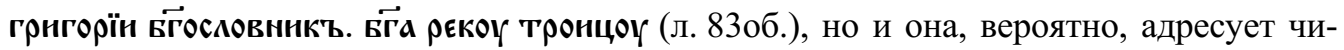
тателя к триадологии той же 39-й гомилии св. Григория.

Особенно важной представляется первая из приведенных цитат. Известно, что в переводе сочинения Никиты Ираклийского имеются две ремарки с обращением к некоему князю. Первая, найденная еще А. В. Горским и К. И. Невоструевым [Горский, Невоструев 1859: 86, 89, 92], находится в толковании на слово 45 (2-е на Пасху), а точнее, там, где речь идет о трехчастном составе души: вннман сомюбчє кнаже (ГИМ, Син. 954, Л. 63г) ${ }^{29}$. Вторая, как указывает Н. В. Понырко [Понырко 2008: 142], читается в комментарии к гомилии 44 в том месте, где Никита рассуждает о девстве: страшна вєџь кнаже (РГБ, Тр. 8, Л. 144об.). МоЖНО ДобавИТь, чТо бо-

\footnotetext{
${ }^{28}$ В ркп. рьзи, испр. по Син. 954, л. $150 б$.

${ }^{29}$ Ср.: въннман С
} 
лее широкий контекст связывает и эту последнюю вставку с темой трех частей души, о которых экзегет упоминает страницей (пергаменного фолио) выше (Тр. 8, л. 144-144об.) Цитата из толкования к 44 слову св. Григория в «Ирмосах на Крещение» относится к тому же предмету христианской антропологии. Автор толкует ир-

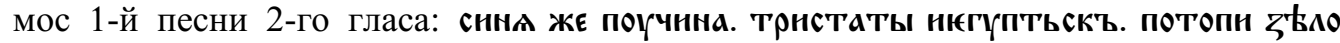
(ГИМ, Воскр. 28-перг., л. 37об.; ср. [Hannick 2006: 50]) и видит в событиях, описанных в книге Исход, прообраз того душевного исцеления, что стало возможным через Христа. Объяснение книжник заимствует из ирмоса 1-й песни 4-го гласа: трн-

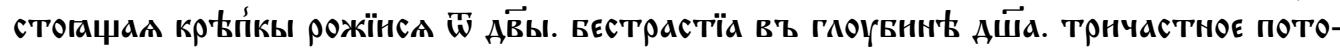
пн мокюса (л. 80об.) «Потопить тристатов» значит, таким образом, придать верное направление всем трем частям души.

Не имеют ли «Ирмосы на Крещение» отношения к рукописной традиции сборника 16 слов Григория Богослова с толкованиями Никиты Ираклийского? Представляется весьма возможным, что записи с упоминанием князя в списках перевода этих толкований принадлежат составителю толкований к «Ирмосам на Крещение». В обоих случаях перед нами обращение к «христолюбивому князю» в контексте излагаемого св. Григорием учения о трех частях души.

Н. В. Понырко считает, что рассмотренные ремарки принадлежат переводчику толкований Никиты на славянский язык [Понырко 2008: 143]. Между тем совершенно очевидно, что мы имеем дело с попавшими в основной текст маргиналиями, сделанными на полях одной из рукописей сборника 16 слов, к которой восходят некоторые дошедшие до нас списки. Они разрывают структуру предложения: и ВЪНОГҚЪААКМа КЪ БААГОУ ЖЕ ОГЧАСТНЮ И ПОХОТНЮ ВЫСАСА. ВЪННМАН ХОМЮБЬЧЕ КНАЖЕ. ПО ЗАКОАЕННН АГНЬЦА МАЖЕТЬ КРОВНЮ СВОКГО АОМОУ ПРАГЫ (Тр. 8, Л. 113Об.);

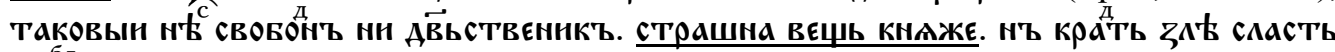
и ба бывакть (Тр. 8, л. 144об.) Эти записи на полях должны были быть сделаны достаточно рано: первая из указанных фраз имеется во всех старших пергаменных списках XIV в., вторая - в большинстве из них (в Син. 43 этой ремарки нет, а в Син. 954 она выскоблена). Это согласуется с высказанными выше соображениями о датировке «Ирмосов на Крещение».

Помимо сборника 16 Слов Григория Богослова с комментариями Никиты Ираклийского эпистолограф пользовался, вероятно и какими-то другими сочинениями. Не вполне ясно, откуда заимствовано разъяснение стиха Пс. 90:13. Близкую аналогию находим у Феодорита Кирского, чье толкование на Псалтырь было переведено на славянский язык еще в древнеболгарскую эпоху:

\begin{tabular}{|c|c|}
\hline & Феодорит Кирский \\
\hline 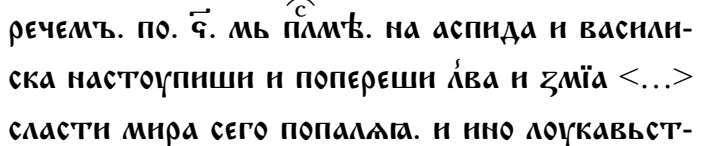 & 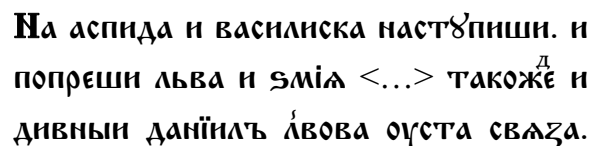 \\
\hline
\end{tabular}


во Жнтї̈а сеГО. ПОАОБно ЕСТЬ АаннмОУ ъаГРАЖЬШЕМОУ ОУСТА А́ВОВА. Н ПАВАОУ НЕ ВРЕ-

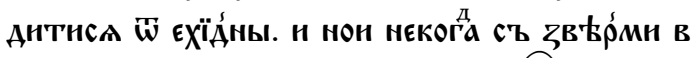
КОВYESЬ ZаТВОРЕНЪ. НЕВРЕАНМЪ БЫ.

(Волок. 659, л. 82-82об.)
ТАКОЖАЕ САавНЫН ПавЕАЪ. НЕ ПРїАТҚ ПакостН Ф ЕХНАНЫ. ТАКОЖАЕ НОН СО

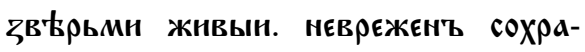
НЕн' БЫСТЬ

(РГБ, МДА 24, л. 240)

Как видим, однако, дословных совпадений с текстом Феодорита «Ирмосы на Крещение» не имеют. Не исключено, что перед нами общее для экзегетов место, а русский книжник пользовался каким-то неразысканным пока источником ${ }^{30}$.

Представляет интерес противопоставление рая (земного Эдема) и неба: надєжю

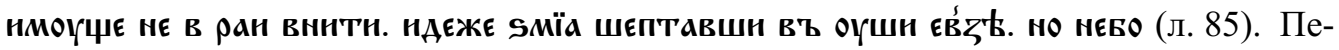
ред последним словом можно предполагать гаплографический пропуск предлога на. Близкую аналогию находим в слове Епифания Кипрского на Великую субботу, славянский перевод которого известен уже по сборнику Клоца и Супрасльской рукописи XI в., а в XII в. оказал влияние на Кирилла Туровского [Рождественская 1987: 424]. Приводим соответствующее место по Супрасльской рукописи: оүстрағањ тА оүЖе (!) въ ран. нъ на неБесъскЫн прЊсто (!) [Займов, КаПаЛДо 1983: 470] ${ }^{31}$.

Весьма любопытно и то, какие именно святые избраны автором для демонстрации власти человека - не только мужей, но и жен - над бесами и самим сатаной после воплощения Христа. Он упоминает свв. Марину, Варвару, Киприана и Иустину. Имя великомученицы Варвары вызывает меньше всего вопросов: она относится к числу наиболее почитаемых православными христианами святых. Ее житие знали на Руси уже в XI в., а мощи, по преданию, были перенесены в Киев в домонгольское время [Бугаевский и др. 2003: 560-561]. Здесь же книжник, по-видимому, неточно цитирует канон 2-го гласа св. вмц. Варваре, автором которого считается прп. Стефан

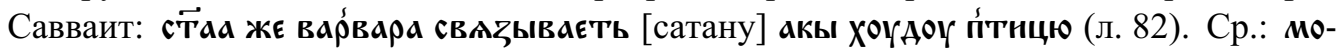

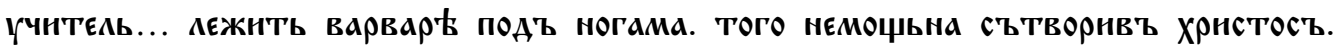
гако Xoy,Aor съваза птнцю (Минея служебная на декабрь, ХІІІ в. РГАДА, Син. тип. 97, л. 21об.) ${ }^{32}$. Упоминание св. вмц. Марины (марнна стала. молотомъ вїашє

${ }^{30}$ Следует отметить, что фрагменты толкований Феодорита в ином переводе (древнерусском, XII в.) читаются в катене на Псалтырь (ее греческий архетип пока не разыскан). К сожалению, проверить, пользовался ли этим источником автор изучаемого памятника, невозможно: доступный текст катены обрывается (вероятно, вследствие утраты в протографе) после Пс. 84:10. См.: [Вершинин 2017] и нашу статью об этом памятнике в настоящем сборнике.

${ }^{31}$ Русские списки памятника известны с XV в. В некоторых из них также пропущен предлог, что показывает распространенность подобной описки: оүстраґаю Же ТА оүЖЕ не в ран. но нБНЫН престоль (Тр. 750, л. 83).

32 Точно так же - и в аналогичном контексте - характеризует вмч. Варвару составитель Тол-

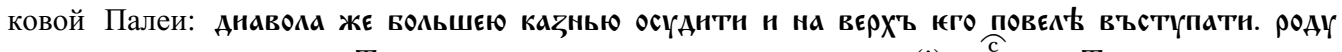

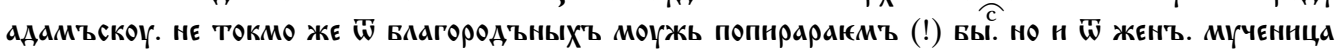
оуво стага варвара. акн Хоуду Птнцю свАза н (Палея 1892: 77-78). 
вЊса, л. 82) является, вероятно, отсылкой к ее мучению, сохранившиеся русские списки которого не старше конца XV в. [Творогов 2008: 80] ${ }^{33}$, но текст обнаруживает признаки гораздо большей древности ${ }^{34}$. Не исключено, однако, использование известного в Византии иконографического сюжета, изображающего св. Марину, побивающую демона молотом [Антонов, Майзульс 2011: 84]; впрочем, аналогичные древнерусские изображения нам неизвестны. Исполнена многозначительного умол-

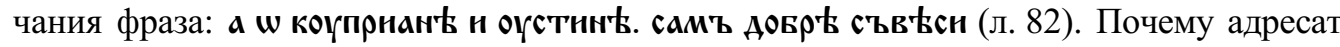
должен быть хорошо осведомлен о житии именно этих святых? Наиболее логичный ответ заключается в том, что празднование памяти Киприана и Иустины находилось в близкой связи с именинами князя, для которого было предназначено послание. В один день с Киприаном и Иустиной (2 октября) на Руси вспоминали подвиги Андрея Юродивого, из чего можно было бы сделать вывод, что адресат толковых ирмосов был крещен во имя св. Андрея. Когда установлена упомянутая память Андрея Юродивого, связанная с распространением нового праздника - Покрова Пресвятой Богородицы, установленного, как считается, Андреем Юрьевичем Боголюбским, доподлинно не известно, но отрывки из жития святого читаются под 2 октября (а также под другими числами того же месяца) в обеих редакциях Пролога (краткой и пространной), начиная с древнейших списков конца XII - XIV в. [Молдован 2000: 106-107].

Рискуя получить упрек в следовании idée fixe - желанию точно атрибутировать памятник славянского средневековья, для которого анонимность была почти нормой, - позволим себе высказать предположение, заслуживающее проверки. Одним кандидатов в первые читатели «Ирмосов на Крещение» мог быть, на наш взгляд, уже упомянутый Андрей Юрьевич. К сожалению, из текста памятника нельзя извлечь дополнительных сведений об адресате. В частности, единожды употребленный термин старьншнна имеет книжное происхождение [см.: Завадская 1989] и не обязательно отсылает к политическим реалиям Древней Руси. Однако в переписке с Андреем Боголюбским находился Кирилл Туровский, что известно из проложного жития святителя [Сухомлинов 1858: 2]. Между тем в нашем послании имеются некоторые черты, сближающие памятник с доподлинными творениями туровского епископа. Это не только заимствования из толкований Никиты Ираклийского (а также, вероятно, из Слова Епифания Кипрского), но и общий эпистолярный оборот,

33 Древнейшая южнославянская рукопись, содержащая упомянутый памятник - Бдинский сборник (Бельгия. Гент. Университетская библиотека, Slav. MS 408) - старше: она относится к концу XIV или началу XV в. и является копией манускрипта 1360 г. [Petrova-Taneva 2001]. Издание греческого оригинала (BHG 1165) см.: [Usener 1886].

${ }^{34}$ Не имея возможности для подробного анализа, отмечу форму имперфекта 3-го лица мн. числа тє́́zахоуть (Тр. 678, л. 309об.), предполагающую посредство относительно раннего древнерусского списка. Из редкой и/или архаической лексики можно указать, например: кУмнрожрєць (л. 306),

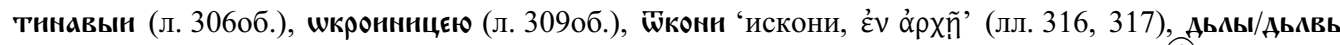

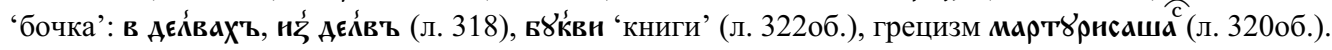




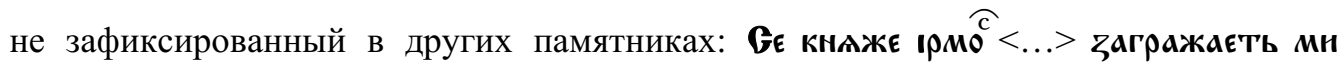

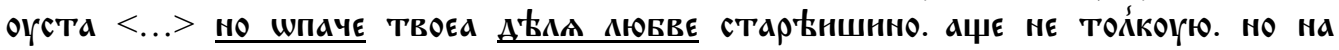
памать ти прнношоу... (л. 85). Ср. в Слове на Новую неделю: «Мы же нищи есмы словом и мутни умом... но обаче любьве дъля сущая со мною братья мало нъчто скажем...» [Еремин 1957: 415]. Сходство усиливается соседством этого оборота в обоих случаях с самоуничижительной формулой. Отметим также прилагаемый к первоверховному апостолу эпитет павєлъ Бгогласїа троуБа (л. 84об.), не относящийся к числу распространенных и имеющий близкую аналогию в молитве Кирилла Туровского в четверг по утрени: «святыи Павел... церковная богогласная труба» [Рогачевская 1999: 120]. Любопытна парафраза в 8-й песни: вместо газыкъ

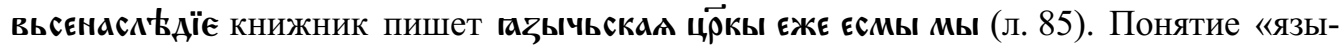
ческая церковь» (то есть церковь от «язык» - новокрещенных народов), встречающееся у апостола Павла (Рим. 16:4: «и вся церкви языческия») и в гимнографии («языческая неплодящая церковь» в ирмосе 3-й песни 2-го гласа; однако в древнем славянском переводе - газычна, см. [Hannick 2006: 54]) является одним из наиболее часто цитируемых топосов у Кирилла Туровского [Еремин 1957: 412, 413; 1958: 339, 342]. Поэтому авторство епископа XII в. отнюдь не исключено, хотя эта догадка нуждается в тщательной проверке.

Толкования на крещенские ирмосы издаются ниже по единственной известной рукописи - РГБ, Волок. 659, л. 80-86. Надстрочные знаки (кроме паерка) не воспроизводятся, киноварь передается полужирным начертанием; толкуемые автором фрагменты ирмосов выделяются кавычками. В левом столбце указываются источники библейских цитат и аллюзий (где их можно точно определить), в буквенных сносках - гимнографические источники, не относящиеся к толкуемым ирмосам.

Для удобства понимания публикуемых толкований вначале приводим текст самих ирмосов 2-го гласа по Воскресенскому Ирмологию конца XII в.

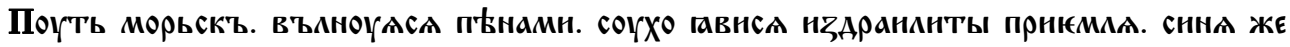

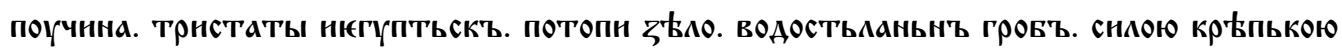
Аєсннцею вмадычьнєю : - (ГИМ, Воскр. 28-Перг., Л. 37об.)

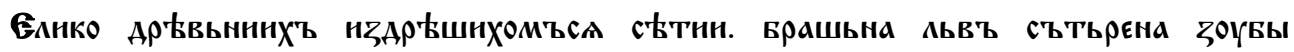
РААОУКМЪСА. И РАШНРАКМЪ ОУСТА САОВО ПАЕТОУЩЕ. ШТЪ САОВЕСЪ ПЬННГа. КЖЕ W НАСЪ вна Всте Аарованні $\because$ (л. 41-41об.)

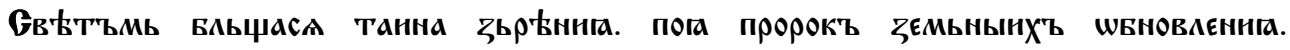

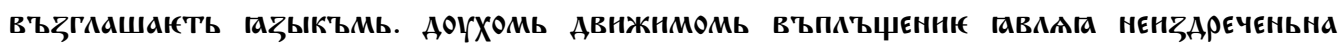

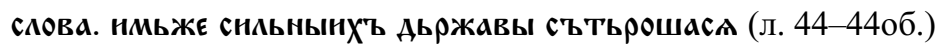

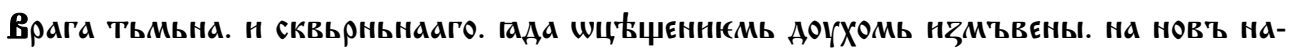
СТАХОМЪ НЕБААZНЬНЪ ПОУТЬ. ВОААЧЬ ВЪ МЕПРЬСТУПЬНОУ РААОСТЬ. КАНН'МВ ПРЕСТОУПЬноҮ. нМьже БогЪ прнмнрнсА : 


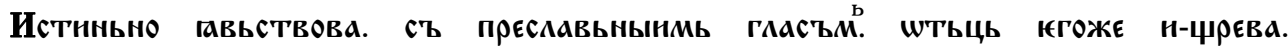

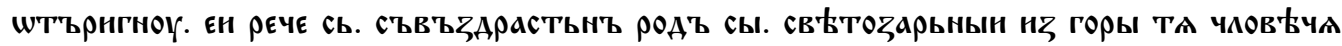
РОАА. САОВО ЖЕ МОК ЖНВО И ЧАОВ ҚКЪ ПРОМЫШАЕННКМЬ $\because$ (Л. 49об.-50)

ИсПААН вОАОЮ. ЪМНЕВЫА ГААВЫ. ПЕџЬНАаГО вЫСОКАаГО ПААМЕНЕ. ОУНОША НМОУЧН

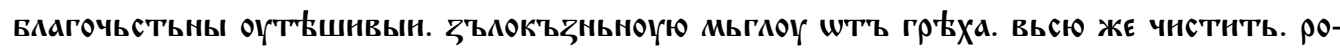
сою АОуХовьною : - (л. 52об.)

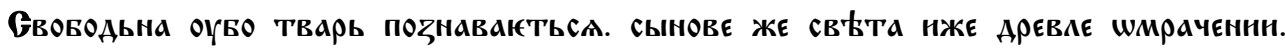

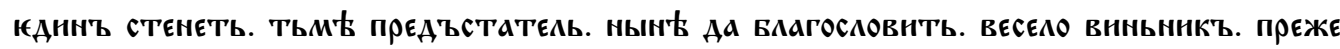
страстьноң. газыкъ вьсенасльдїЕ : レ (Л. 56)

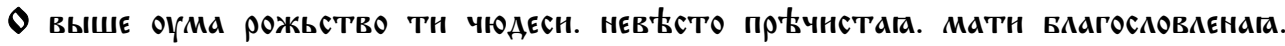
КЮЖЕ ПОЛОУЧЬШЕ. СЪВЬРШЕНО СЪПА[СЕ]ННІ. АОСТОННО СЪАТВАКМЪ ГОКО БААГОААТЕАЮ. ААрЫ носАџЕ. П'Сени и ХВАленнга $\because \backsim$ (Л. 60об.-61)

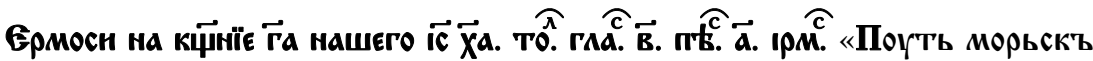

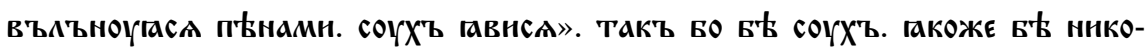

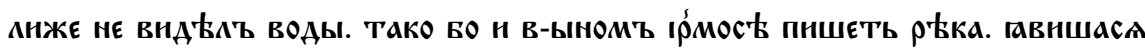

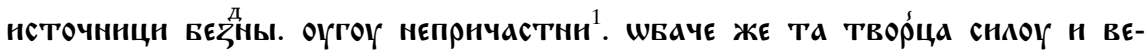

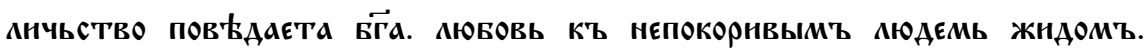

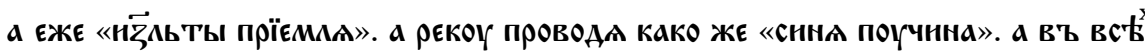

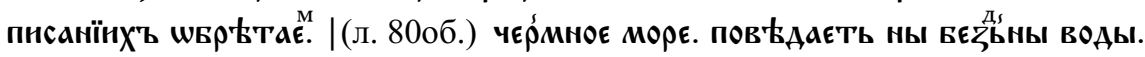
многажЫЫ БО и мы МолвН. ЕГАа оцЪрнмъ ГАовость ${ }^{2}$ воды. страшно т́ма СА

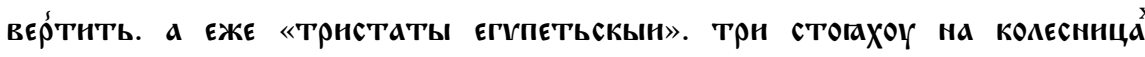

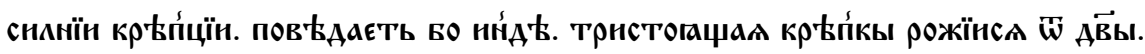
Бестрастїа въ гАоуБнн' Аш̈а. трнчастное потопн молюсА. Боудн нама

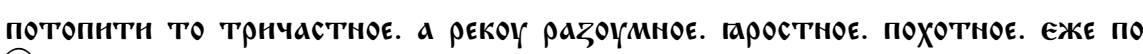

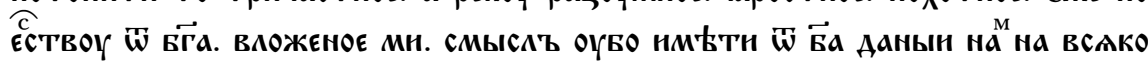

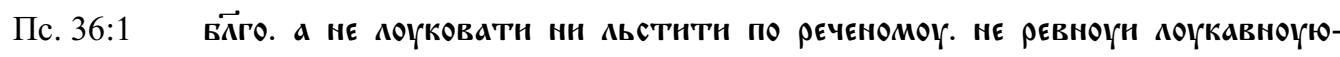

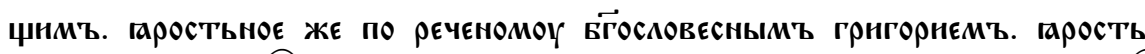

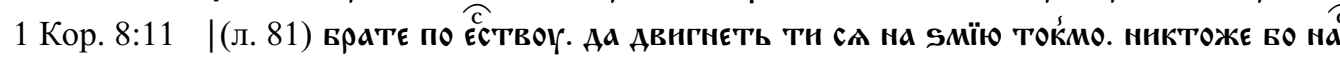

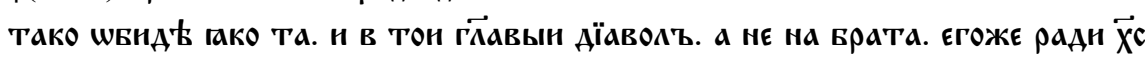

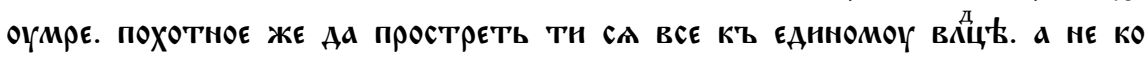

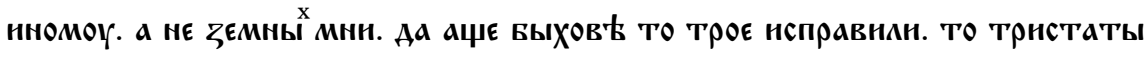

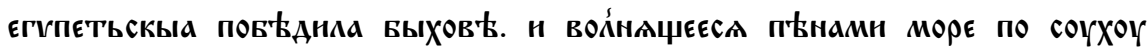

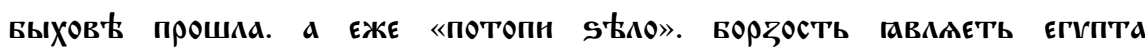

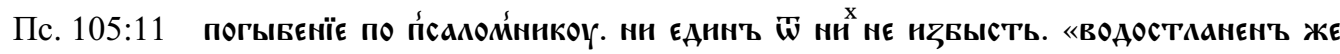
ГРОБЪ». НАСмНХаГАСА ЕГИПТАнОМЪ ПНШЕТЬ. А СААВА И ХВААА ПНШЕТЬ Н "СН-

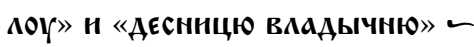




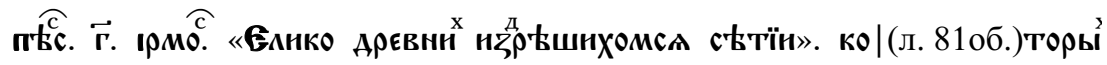

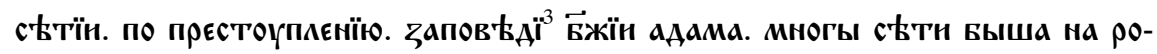

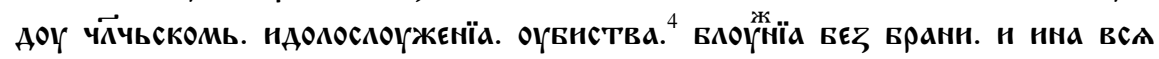

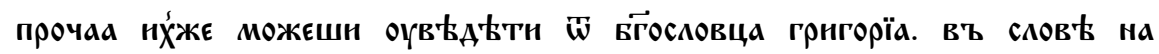

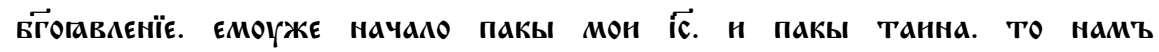

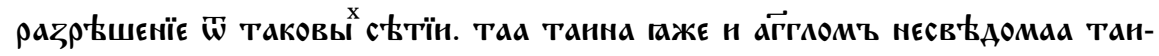

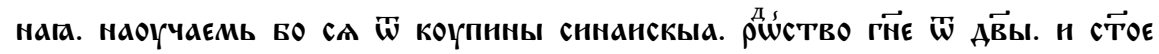

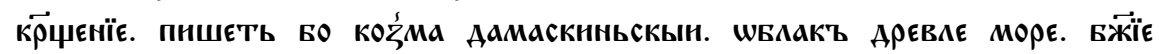

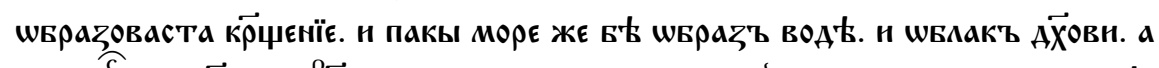

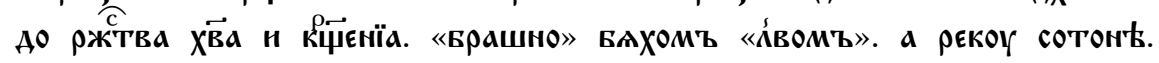

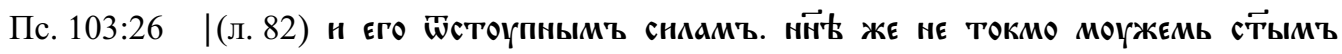

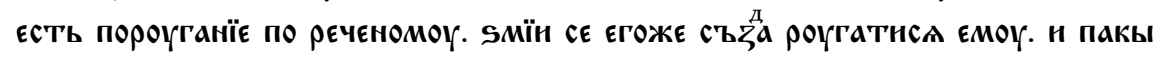

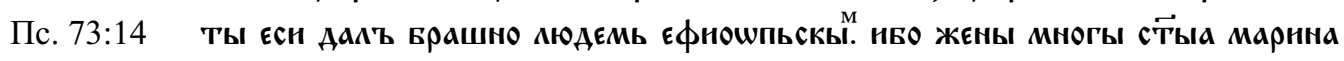

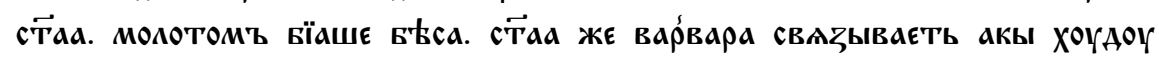

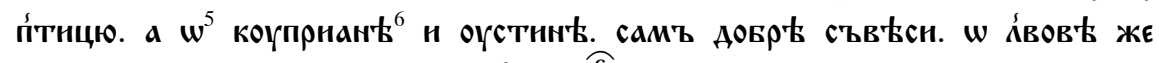
Пс. 90:13 «СЪТРЕнїн ЗХБЪ» речемъ. по.

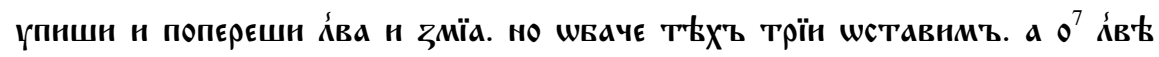

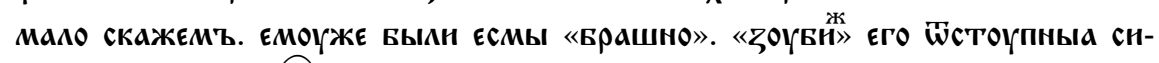

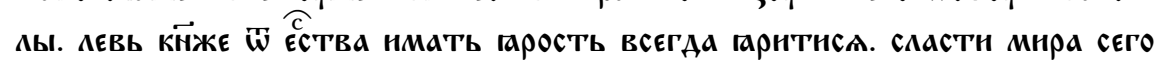

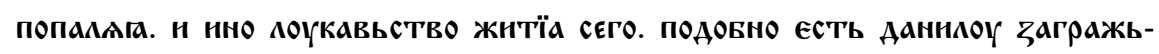

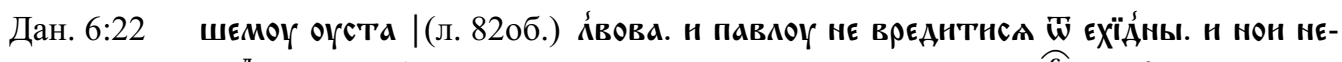

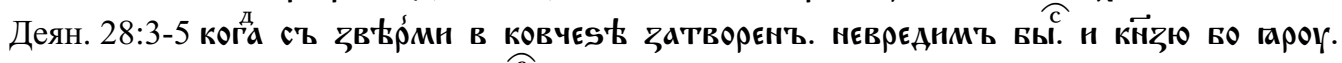

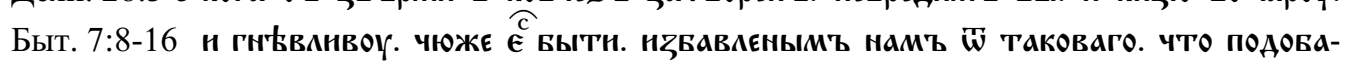

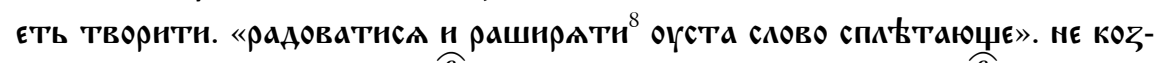

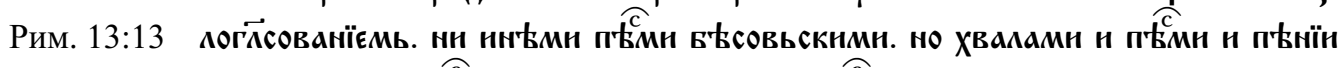

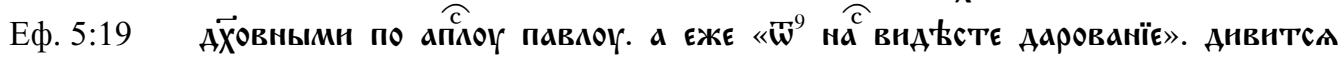

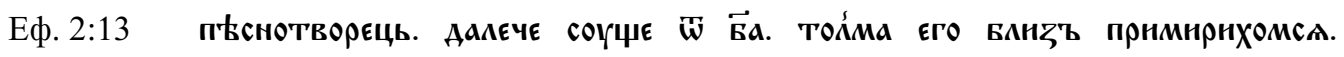

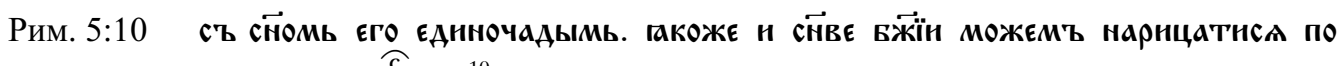

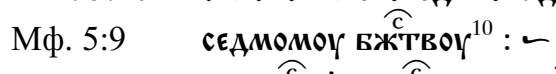

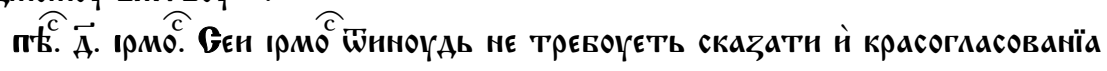

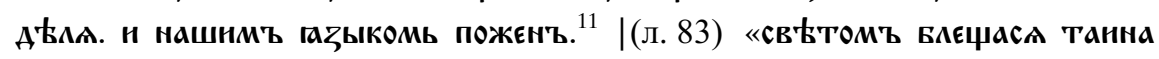

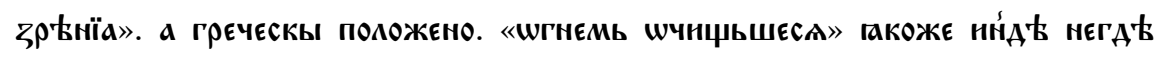

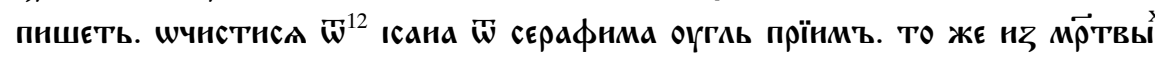

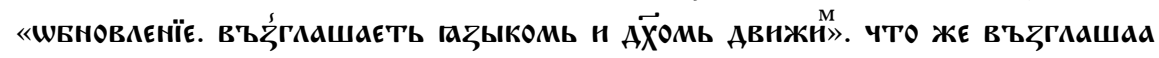

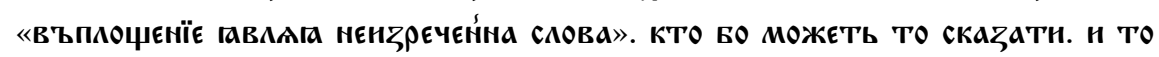

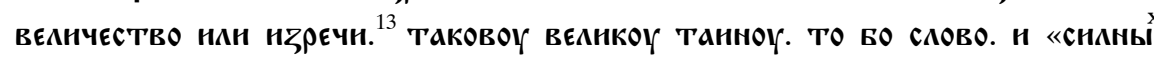




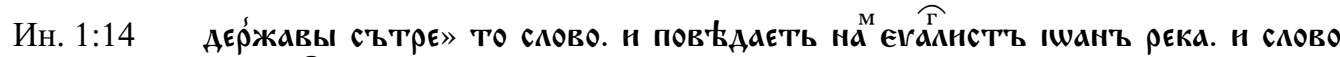

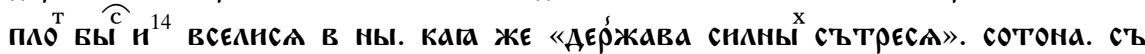

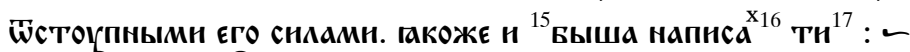

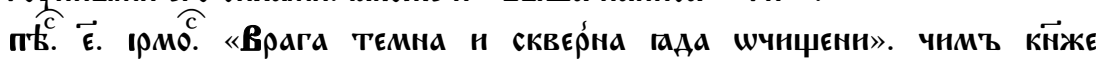

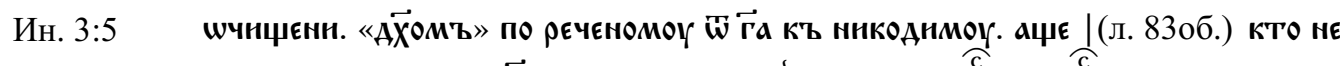

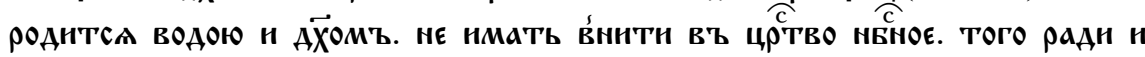
ТВОРЕЦЬ ПНШЕТЬ. “АХХХОМЪ НЗМОВЕНН» ПО ТОМЪ И «НА НОВЪ НАСТАХОМЬ НЕ-

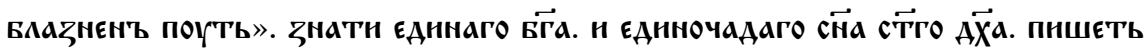

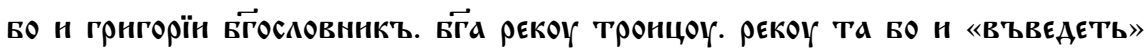

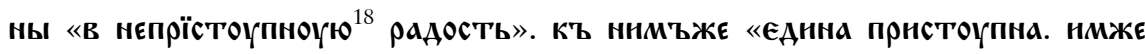
БЪ прнмнрнсА»-

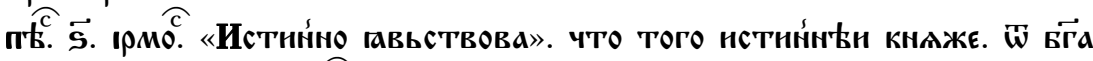

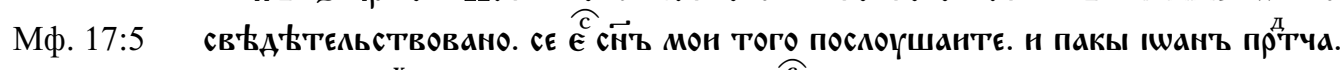

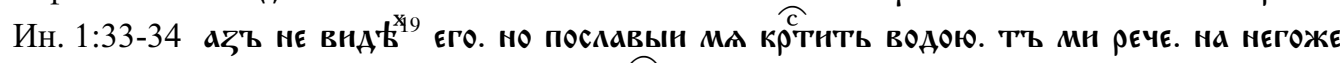

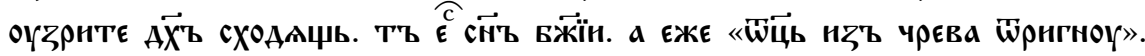

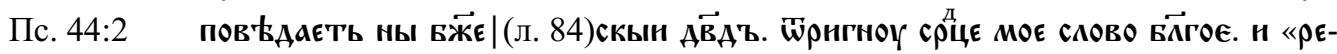

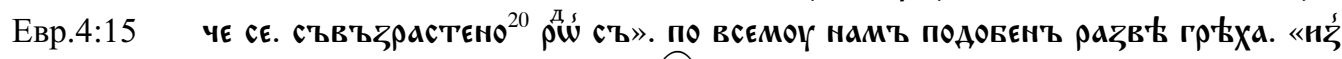
ГОРЫ» ЖЕ "РОАа Ч

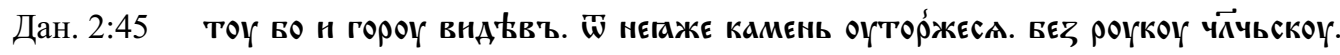
Пс. 67:16 нБО и псаломннкъ. гора Бжї̈а гора тоучна. и прочаа «слово Же МОе Жнво».

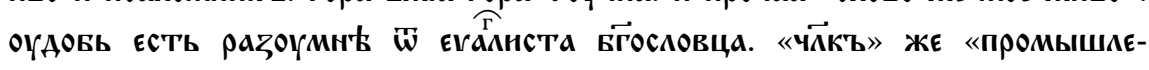

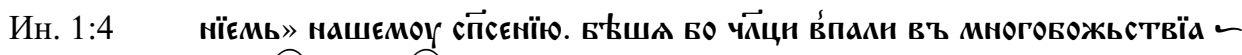

ПЪ.

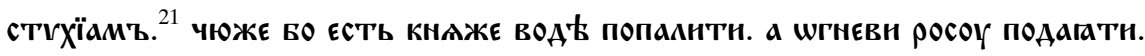

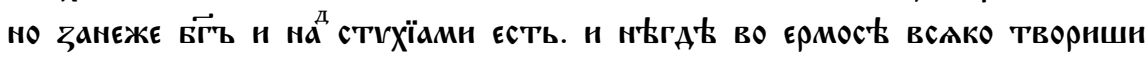

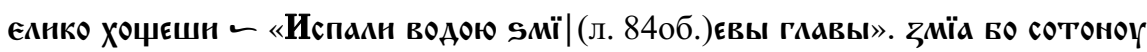
ГАЕТЬ. Н БСТОУПНЫа ЕГО сНАЫ. «ПЕџНЫН» ЖЕ «ВЫСОКЫН ПААМЕНЬ». Н КОГО

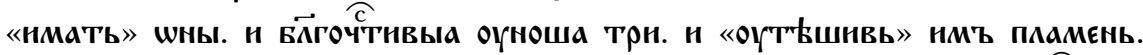

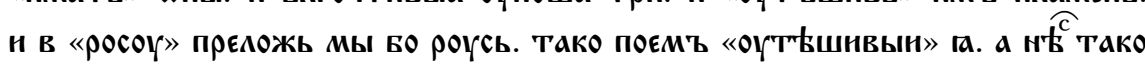

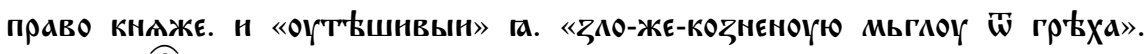

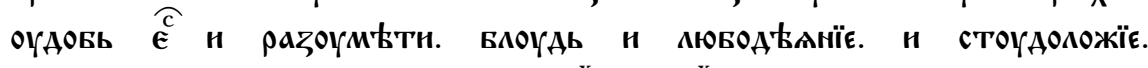

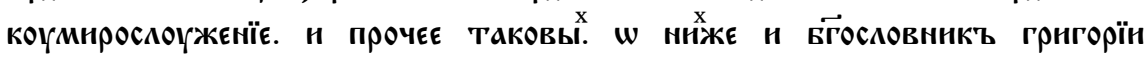

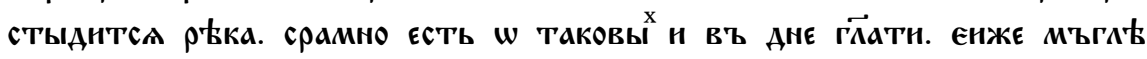

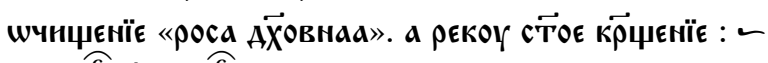

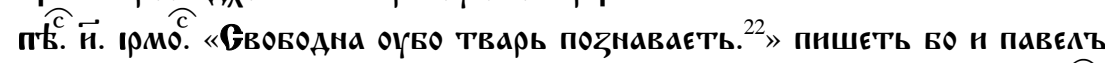

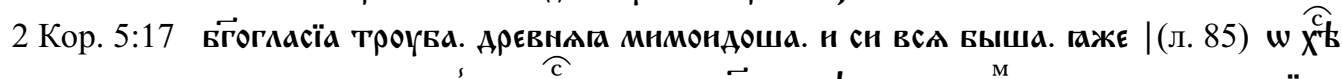

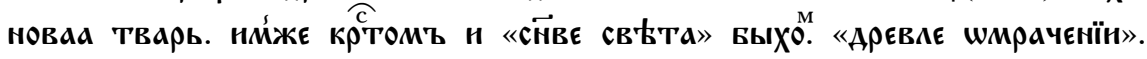




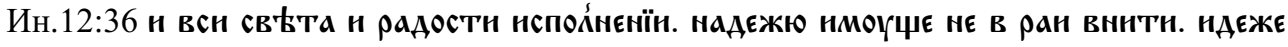

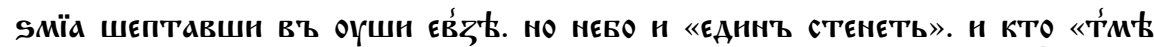

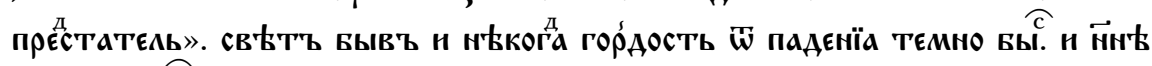

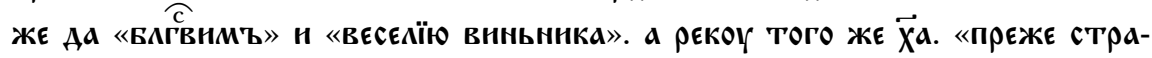
СТНОЕ» ДОЗЫЧЬСКАА ЦРКЫ ЕЖЕ ЕСМЫ МЫ.

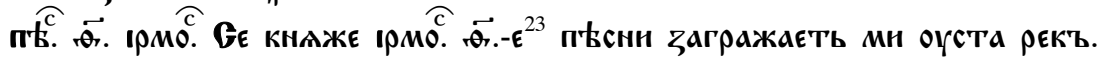

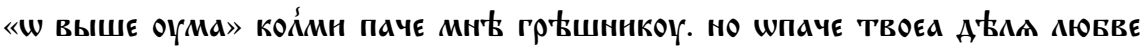

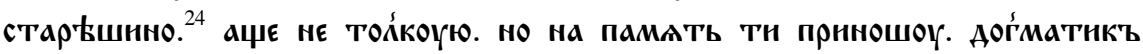

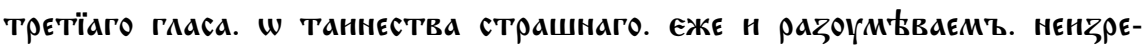
чен́нO ПРЕБЫВАЕТЬ. Н ВНАН|(Л. 85Об.)МОЕ НЕ ПОСТЫҚАЕТСА. Н ПАКЫ

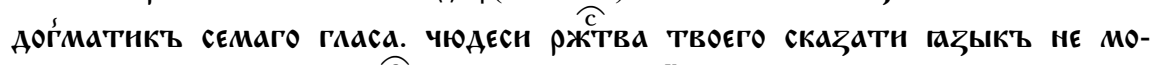

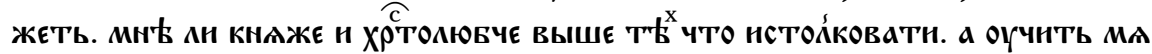

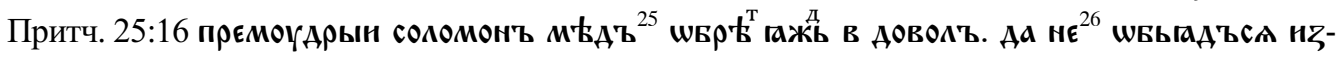
БАЮЕШН. И ПаКЫ ТОН. СНОУ ХРАННСА СЪТВАРАТН КННГЫ МНОГЫ. Н ПОВБААЕТЬ

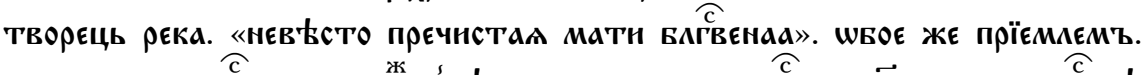

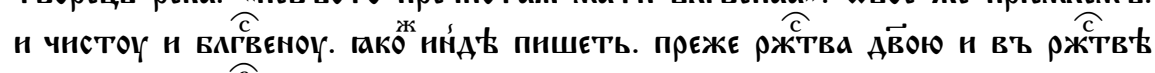

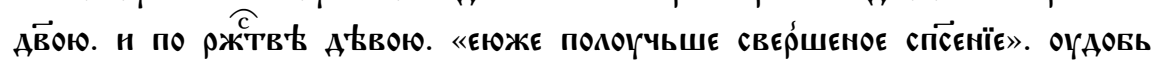

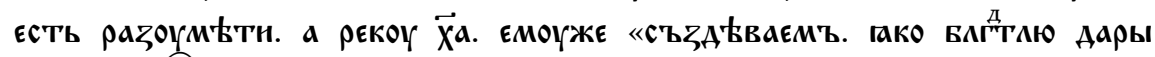

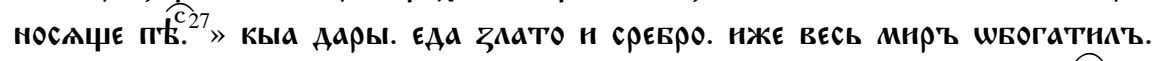

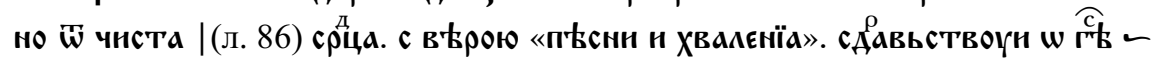

${ }^{1}$ Испр. писцом из нєпрнчастннци (ци зачеркнуто киноварью) ${ }^{2}$ Так в ркп., вероятно, вместо глоүвость ${ }^{3}$ Испр. писцом из заповњдїн (и зачеркнуто киноварью) ${ }^{4}$ Так в ркп. ${ }^{5}$ Вписано над строкой ${ }^{6}$ о подскоблено ${ }^{7}$ Вписано над строкой ${ }^{8}$ В ркп. рашнтн; рл вписано над строкой другим почерком. Ср. аналогичную ошибку (?) в Коломенской Палее 1406 г.: рашнвъ вм. рашнрнвъ [СЛДРЯ XI-XIV 10: 320] ${ }^{9}$ Так в ркп., вместо $w^{10}$ Так в ркп., вероятно, вместо влжгітвог ${ }^{11}$ Так в ркп., вместо положєнъ (?) ${ }^{12}$ Написано по ошибке ${ }^{13}$ Испр. на изрєци другим почерком ${ }^{14}$ Вписано над строкой ${ }^{15-16}$ Так в ркп. ${ }^{17}$ Испр. писцом из тн (надстрочная буква подскоблена) ${ }^{18}$ ї испр. из є другим почерком ${ }^{19}$ Испр. на $\mathbf{B} \mathbf{b} \mathbf{A}^{\mathbf{x}}$ другим почерком ${ }^{20}$ Испр. на съвъ弓растєнъ другим почерком ${ }^{21}$ В ркп. стухїахїамъ. ${ }^{22}$ Так в ркп., вероятно, вместо познаваєть ${ }^{{ }^{2}}{ }^{23}$ В ркп. $\overrightarrow{\boldsymbol{\epsilon}}^{24}$ Так в ркп. ${ }^{25} \mathbf{b}$ испр. на є другим почерком ${ }^{26}$ Вписано над строкой ${ }^{27}$ Вероятно, слово п穻 написано здесь по ошибке (ср. ниже: пьсни и Хвалєнїа).

гавншасА нсточннцн Бец̆НЫ. оугоу непрнчастнн: из ирмоса 1-й песни 4го гласа, ср.: ГАвнша сА нсточьннцы БезАьныА. югоҮ непрнчастьнн... [Hannick 2006: 110] 


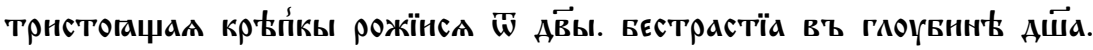
трнчастное потопн момюсА: из ирмоса 1-й песни 4-го гласа, ср.: Трн-

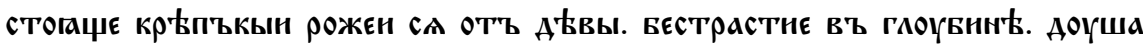
трнчастное потопн молю сA... [Hannick 2006: 110].

агГАомъ несв'Домаа таннага: из богородична воскресного отпусти-

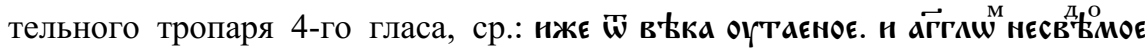
танньство... (Тр. 242, л. 563).

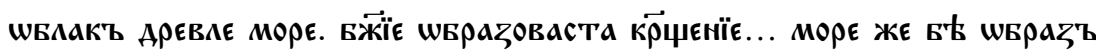
вод'. и швлакъ д $\vec{X}$ Овн: из 7-й песни канона Сретению (св. Космы Маюм-

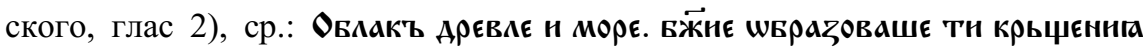

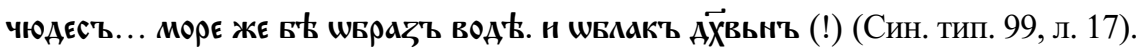

шчнстнсл $\boldsymbol{W}$ Ісана $\boldsymbol{w}$ серафнма оүгаь прїнмъ: из 5-й песни канона Сретению (св. Космы Маюмского, глас 3), ср.: Очнстнса нсанга. серафнма оүгаь прннмовавъ... (Син. тип. 104, л. 14).

всАко творншн ЕАнко Хочєшн: ИЗ ирмоса 8-й Песни 6-Го гласа, ср.: всА во творнши Хрнсте єлнко Хоцєшн... [Hannick 2006: 184].

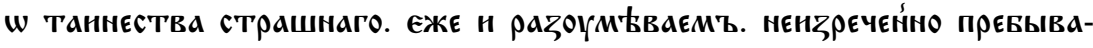

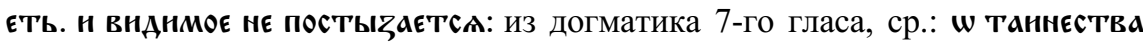

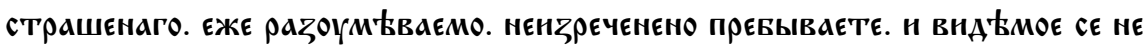
ПОСТНZаЕТеСА... (Тр. 444, Л. 29об.-30).

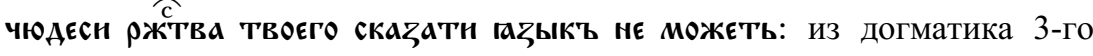

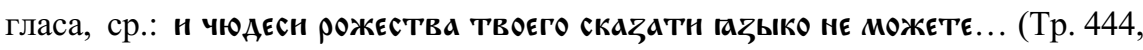
л. 83об.).

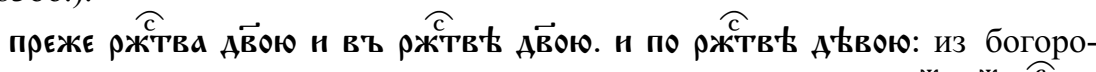

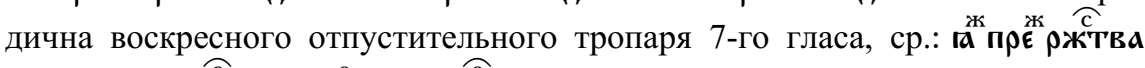

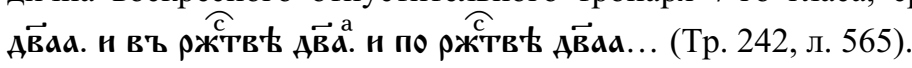

\section{Рукописные источники}

Волок. 13 - РГБ, собр. Иосифо-Волоколамского монастыря, № 13, библейский сборник, третья четверть XV в.

Волок. 659 - РГБ, собр. Иосифо-Волоколамского монастыря, № 659, сборник, 1530-е гг.

Воскр. 28-перг. - ГИМ, собр. Воскресенское, пергаменное, № 28, ирмологий, конец XII в.

Кир.-Бел. 19/1096 - РНБ, собр. Кирилло-Белозерского монастыря, № 19/1096, сборник, первая четверть XV в. 
МДА 24 - РГБ, собр. Московской духовной академии, № 24, толковая Псалтирь Феодорита Кирского, XVII в.

Оболенск. 161 - РГАДА, ф. 201 (собр. М. А. Оболенского), Великая Минея четья (август), ок. 1538 г.

Овчин. 215 - РГБ, собр. П. А. Овчинникова, № 215, толковые каноны, XVII в.

Прян. 8 - РГБ, собр. Г. М. Прянишникова, № 8, толковая Псалтирь, сер. XVI в.

Син. 43 - ГИМ, собр. Синодальное, № 43, сборник 16 слов Григория Богослова с толкованиями, конец XIV в.

Син. 954 - ГИМ, собр. Синодальное, № 954, сборник 16 слов Григория Богослова с толкованиями, конец XIV в.

Син. тип. 97 - РГАДА, ф. 381 (собр. Московской Синодальной типографии), минея служебная на декабрь, ХІІІ в.

Син. тип. 99 - РГАДА, ф. 381 (собр. Московской Синодальной типографии), минея служебная на январь, XI-XII в.

Син. тип. 104 - РГАДА, ф. 381 (собр. Московской Синодальной типографии), минея служебная на февраль, ХІІ в.

Тр. 8 - РГБ, собр. Троице-Сергиевой лавры, № 8, сборник 16 слов Григория Богослова с толкованиями, конец XIV в.

Tp. 11 - РГБ, собр. Троице-Сергиевой лавры, № 11, Златая цепь (1-го типа), конец XIV в.

Tp. 15 - РГБ, собр. Троице-Сергиевой лавры, № 15, Мерило Праведное, XIV в.

Tp. 242 - РГБ, собр. Троице-Сергиевой лавры, № 242, Устав церковный, XVI в.

Тр. 444 - РГБ, собр. Троице-Сергиевой лавры, № 444, Октоих, XV в.

Tp. 678 - РГБ, собр. Троице-Сергиевой лавры, № 678, минея четья на июль, XV и XVI вв. (конволют).

Тр. 750 - РГБ, собр. Троице-Сергиевой лавры, № 750, сборник, XV в.

Увар. 589 - ГИМ, собр. А. С. Уварова, № 589-4은, сборник, конец XIV в.

Унд. 546 - РГБ, собр. В. М. Ундольского, № 546, толковые каноны, 1624 г.

F.п.1.39 - РНБ, F.п.1.39 (б. собр. Ф. А. Толстого), сборник, вторая половина XIII в.

\section{Литература}

Аксенова $2011-$ Г. В. Аксенова. Русская книжная культура на рубеже XIX-XX веков. М., 2011.

Алексеев 1988 - А. А. Алексеев. К истории русской переводческой школы XII в. // ТОДРЛ. Л., 1988. Т. 41. С. 154-196.

Антонов, Майзульс 2011 - Д. И. Антонов, М. Р. Майзульс. Демоны и грешники в древнерусской иконографии: семиотика образа. М., 2011.

Бабицкая 1995 - М. Б. Бабиџкая. Источники Изборника XIII века (Cod. St. Petersburg, GPB, Q.n.1.18) // Byzantinoslavica. 1995. T. 56. S. 631-635. 
Бруни $2004-$ А. М. Бруни. Өво入о́үос. Древнеславянские кодексы Слов Григория Назианзина и их византийские прототипы (Россия и Христианский Восток. Библиотека. Вып. 6). М.-СПб., 2004.

Бруни 2013 - А. М. Бруни. К сопоставительному изучению византийской и древнейшей славянской традиций Толкований Никиты Ираклийского к Словам Григория Богослова // Палеография, кодикология, дипломатика. Современный опыт исследования греческих, латинских и славянских рукописей и документов. Материалы Международной научной конференции в честь 75-летия доктора исторических наук, члена-корреспондента Афинской Академии Бориса Львовича Фонкича. Москва, 2728 февраля 2013 г. М., 2013. С. 29-42.

Бугаевский и др. 2003 - А. В. Бугаевский, П. И. Жаворонков, И. В. Жиленко. Варвара. Мощи и почитание // Православная энциклопедия. М., 2003. Т. VI. С. 560-561.

Буланин 1991 - Д. М. Буланин. Античные традиции в древнерусской литературе XI-XVI вв. München, 1991.

Буланин 2014 - Д. М. Буланин. Приложение III. К спорам о славянском переводе «историй» псевдо-Нонна // Каталог памятников древнерусской письменности XIXIV вв. (Рукописные книги) / Отв. ред. Д. М. Буланин. СПб., 2014. С. 459-481.

Вершинин $2017-K$. В. Вершинин. Славянский перевод неизвестной катены на Псалтырь // Древняя Русь. Вопросы медиевистики. 2017. № 3 (69). С. $23-24$.

Виноградов 1915 - В. П. Виноградов. Уставные чтения. Сергиев Посад, 1915. Вып. 3.

Горский, Невоструев 1859 - А. В. Горский (прот.), К. И. Невоструев. Описание славянских рукописей Московской Синодальной библиотеки. Отд. 2. Писания святых отцев. М., 1859. Ч. 2.

Еремин 1955, 1957, 1958 - И. П. Еремин. Литературное наследие Кирилла Туровского // ТОДРЛ. М.-Л., 1955. Т. 11. С. 342-367; 1957. Т. 13. С. 409-426; 1958. Т. 15. С. 331-348.

Завадская $1989-$ С. В. Завадская. К вопросу о «старейшинах» в древнерусских источниках XI-XIII вв. // Древнейшие государства на территории СССР. Материалы и исследования, 1987 г. М., 1989. С. 36-42.

Займов, Капалдо 1983 - И. Займов, М. Капалдо. Супрасльский, или Ретков сборник. София, 1983. Т. 2.

Зализняк 2008 - А. А. Зализняк. Древнерусские энклитики. М., 2008.

Клосс 1980 - Б. М. Клосс. Никоновский свод и русские летописи XVI-XVII веков. М., 1980.

Крутова 2002 - М. С. Крутова. Златая цепь (по Троицкому списку). Тексты. Исследования. Комментарии. М., 2002.

Молдован 1984 - А. М. Молдован. «Слово о законе и благодати» Илариона. Киев, 1984.

Молдован 2000 - А. М. Молдован. «Житие Андрея Юродивого» в славянской письменности. М., 2000. 
Молдован 2013 - А. М. Молдован. К текстологии 16 Слов Григория Богослова с толкованиями Никиты Ираклийского // Письменность, литература, фольклор славянских народов. История славистики. XV Международный съезд славистов (Минск, 20-27 августа 2013 г.). Доклады российской делегации. М., 2013. С. 207-228.

Молдован 2016 - A. М. Молдован. Восточнославянская лексика в переводе толкований Никиты Ираклийского на слова Григория Богослова // Труды Института русского языка им. В. В. Виноградова. Вып. 9. История русского языка и культуры. Памяти В. М. Живова. М., 2016. С. 70-85.

Никольский 1892 - Н. К. Никольский. О литературных трудах митрополита Климента Смолятича, писателя ХІІ века. СПб., 1892.

Никольский 1897 - Н. К. Никольский. Описание рукописей Кирилло-Белозерского монастыря, составленное в конце XV века. СПб., 1897.

Палея 1892 - Палея Толковая по списку, сделанному в Коломне в 1406 г. / Труд учеников Н. С. Тихонравова. М., 1892.

Пичхадзе 2011 - A. А. Пичхадзе. Переводческая деятельность в домонгольской Руси: лингвистический аспект. М., 2011.

Плигузов 2008 - А. И. Плигузов. Русский феодальный архив XIV — первой трети XVI века. М., 2008.

Понырко 2008 - Н. В. Понырко. Был ли Климент Смолятич создателем первого славянского перевода Толкований Никиты Ираклийского на 16 Слов Григория Богослова // ТОДРЛ. СПб., 2008. Т. 59. С. 133-143.

Прохоров $1987-$ Г. М. Прохоров. Памятники переводной и русской литературы XIV-XV веков. Л., 1987.

Рогачевская 1999 - Е. Б. Рогачевская. Цикл молитв Кирилла Туровского: Тексты и исследования. М., 1999.

Рождественская 1987 - М. В. Рождественская. Слово Епифания Кипрского о погребении Иисуса Христа и о Иосифе Аримафейском // Словарь книжников и книжности Древней Руси. Л., 1987. Вып. I (XI - первая половина XIV в.). С. 423-425.

СлДРЯ XI-XIV - Словарь древнерусского языка XI-XIV вв. М., 1988-. Т. 1-.

СлРЯ XI-XVII - Словарь русского языка XI-XVII вв. М., 1975-. Вып. 1-.

Соболевский 1910 - А. И. Соболевский. Материалы и исследования в области славянской филологии и археологии. СПб., 1910.

Сухомлинов 1858 - М. И. Сухомлинов. Рукописи графа А. С. Уварова. СПб., 1858. T. 2.

Творогов 2008 - О. В. Творогов. Переводные жития в русской книжности XIXV веков. Каталог. М.-СПб., 2008.

Темчин 2017 - С. Ю. Темчин. Толковые праздничные каноны - неучтенное древнерусское произведение домонгольского периода // Восточная Европа в древности и средневековье. Античные и средневековые общности. XXIX Чтения памяти члена-корреспондента АН СССР Владимира Терентьевича Пашуто. Москва, 1921 апреля 2017 г. Материалы конференции. М., 2017. С. 223-228. 
Ундольский $1870-B$. М. Ундольский. Славяно-русские рукописи В. М. Ундольского, описанные самим составителем и бывшим владельцем собрания, с № 1 по № 579. М., 1870.

Юхименко 2013 - E. М. Юхименко. Традиция составления Четиих Миней в старообрядческой среде // Slavia Orientalis. 2013. T. LXII. № 1. S. 87-97.

Hannick 2006 - Ch. Hannick. Das Altslavische Hirmologion. Edition und Kommentar (Monumenta linguae slavicae dialecti veteris. Fontes et dissertationes. Tom. L). Freiburg I. Br., 2006.

Petrova-Taneva 2001 - M. Petrova-Taneva. The Ghent Manuscript of the Bdinski Zbornik: the Original or a Copy? // Slavica Gandensia. Gent, 2001. Vol. 28. P. 115-144.

Usener $1886-H$. Usener (ed.) Acta S. Marinae et S. Christophori // Festschrift zur fünften Säcularfeier der Carl-Ruprechts-Universität zu Heidelberg. Bonnae, 1886. S. 15-46.

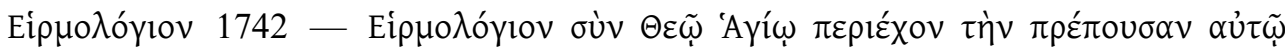

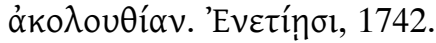

\author{
Konstantin $\boldsymbol{V}$. Vershinin \\ Russian History Institute of the Russian Academy of Sciences \\ (Moscow, Russia) \\ versh-kv@yandex.ru
}

\title{
AN OLD RUSSIAN COMMENTARY ON THE HEIRMOSES FOR THE THEOPHANY
}

The paper contains an examination and a publication of an exegetical epistle of an anonymous churchman to an ancient Russian prince. The piece is known in a single copy which dates back to the 1530s and is entitled "Heirmoses for the Theophany of Our Lord Jesus Christ". It is a scholium on the Slavic heirmoses for the second Theophany canon (by John of Damascus). The scholium bears evidence of the author's familiarity with the Greek original of the heirmoses. Notably, he refers to the tripartite theory of the soul and quotes commentaries of Nicetas of Heraclea on the homilies of Gregory of Nazianzus, which makes the piece a significant evidence of Russian reception of the translation of the named oeuvre. Analysis of the text indicates its early (likely pre-Mongol) origin. A cautious conjecture is made that the epistle was composed by Cyril of Turov for prince Andrei Yuryevich "Bogolyubsky".

Key words: Heirmologion, Gregory of Nazianzus, Nicetas of Heraclea, Cyril of Turov, Old Russian literature, Slavic translated literature 


\section{References}

Aksenova G. V. Russkaya knizhnaya kul'tura na rubezhe XIX-XX vekov. Moscow, 2011.

Alekseev A. A. K istorii russkoi perevodcheskoi shkoly XII v. Trudy Otdela drevnerusskoi literatury. Vol. 41. Leningrad, 1988, pp. 154-196. (In Russ.)

Antonov D. I., Maizuls M. R. Demony i greshniki v drevnerusskoi ikonografii: semiotika obraza. Moscow, 2011.

Babitskaya M. B. Istochniki Izbornika XIII veka (Cod. St.-Petersburg, GPB, Q.n.1.18). Byzantinoslavica. Vol. 56. 1995, pp. 631-635. (In Russ.)

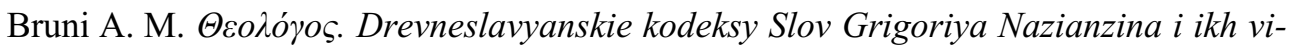
zantiiskie prototipy (Rossiya i Khristianskii Vostok. Biblioteka. No. 6). Moscow-St.Petersburg, 2004.

Bruni A. M. K sopostavitel'nomu izucheniyu vizantiiskoi i drevneishei slavyanskoi traditsii Tolkovanii Nikity Irakliiskogo k Slovam Grigoriya Bogoslova. Paleografiya, kodikologiya, diplomatika. Sovremennyi opyt issledovaniya grecheskikh, latinskikh i slavyanskikh rukopisei i dokumentov. Materialy Mezhdunarodnoi nauchnoi konferentsii v chest' 75-letiya doktora istoricheskikh nauk, chlena-korrespondenta Afinskoy Akademii Borisa L'vovicha Fonkicha. Moskva, 27-28 fevralya 2013 g. Moscow, 2013, pp. 29-42. (In Russ.)

Bugaevskii A. V., Zhavoronkov P. I., Zhilenko I. V. Varvara. Moshchi i pochitanie. Pravoslavnaya entsiklopediya. Vol. 6. Moscow, 2003, pp. 560-561.

Bulanin D. M. Antichnye traditsii v drevnerusskoi literature XI-XVI vv. München, 1991.

Bulanin D. M. Prilozhenie III. K sporam o slavyanskom perevode «istorii» psevdoNonna. Katalog pamyatnikov drevnerusskoi pis'mennosti XI-XIV vv. (Rukopisnye knigi) / Ed. D. M. Bulanin. St.-Petersburg, 2014, pp. 459-481.

Eremin I. P. Literaturnoe nasledie Kirilla Turovskogo. TODRL. Moscow-Leningrad, 1955. Vol. 11, pp. 342-367; 1957. Vol. 13, pp. 409-426; 1958. Vol. 15, pp. 331-348.

Gorskiy A. V., Nevostruev K. I. Opisanie slavyanskikh rukopisei Moskovskoi Sinodal'noi biblioteki. Otd. 2. Pisaniya svyatykh ottsev. Part 2. Moscow, 1859.

Hannick Ch. Das Altslavische Hirmologion. Edition und Kommentar (Monumenta linguae slavicae dialecti veteris. Fontes et dissertationes. Tom. L). Freiburg I. Br., 2006.

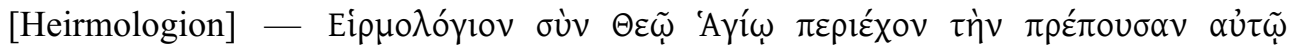

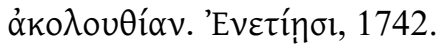

Kloss B. M. Nikonovskiy svod i russkie letopisi XVI-XVII vekov. Moscow, 1980.

Krutova M. S. Zlataya tsep' (po Troitskomu spisku). Teksty. Issledovaniya. Kommentarii. Moscow, 2002.

Moldovan A. M. «Slovo o zakone i blagodati» Ilariona. Kiev, 1984.

Moldovan A. M. «Zhitie Andreya Yurodivogo»v slavyanskoi pis'mennosti. Moscow, 2000.

Moldovan A. M. K tekstologii 16 Slov Grigoriya Bogoslova s tolkovaniyami Nikity Irakliyskogo. Pis'mennost', literatura, fol'klor slavyanskikh narodov. Istoriya slavistiki. XV Mezhdunarodnyi s"ezd slavistov (Minsk, 20-27 avgusta 2013 g.). Doklady rossiyskoi delegatsii. Moscow, 2013, pp. 207-228. (In Russ.) 
Moldovan A. M. Vostochnoslavyanskaya leksika v perevode tolkovanii Nikity Irakliiskogo na slova Grigoriya Bogoslova. Trudy Instituta russkogo yazyka im. V. V. Vinogradova, no. 9. Istoriya russkogo yazyka i kul'tury. Pamyati V. M. Zhivova. Moscow, 2016, pp. 70-85. (In Russ.)

Nikol'skii N. K. O literaturnykh trudakh mitropolita Klimenta Smolyaticha, pisatelya XII veka. St.-Petersburg, 1892.

Nikol'skii N. K. Opisanie rukopisei Kirillo-Belozerskogo monastyrya, sostavlennoe $v$ kontse XV veka. St.-Petersburg, 1897.

Paleya Tolkovaya po spisku, sdelannomu v Kolomne v $1406 \mathrm{~g}$. Trud uchenikov N. S. Tikhonravova. Moscow, 1892.

Petrova-Taneva M. The Ghent Manuscript of the Bdinski Zbornik: the Original or a Copy? Slavica Gandensia. Vol. 28. Gent, 2001, pp. 115-144.

Pichkhadze A. A. Perevodcheskaya deyatel'nost'v domongol'skoi Rusi: lingvisticheskii aspekt. Moscow, 2011.

Pliguzov A. I. Russkii feodal'nyi arkhiv XIV — pervoi treti XVI veka. Moscow, 2008.

Ponyrko N. V. Byl li Kliment Smolyatich sozdatelem pervogo slavyanskogo perevoda Tolkovanii Nikity Irakliyskogo na 16 Slov Grigoriya Bogoslova. Trudy Otdela drevnerusskoi literatury. Vol. 59. St.-Petersburg, 2008, pp. 133-143. (In Russ.)

Prokhorov G. M. Pamyatniki perevodnoi i russkoi literatury XIV-XV vekov. Leningrad, 1987.

Rogachevskaya E. B. Tsikl molitv Kirilla Turovskogo: Teksty i issledovaniya. Moscow, 1999.

Rozhdestvenskaya M. V. Slovo Epifaniya Kiprskogo o pogrebenii Iisusa Khrista i o Iosife Arimafeyskom. Slovar' knizhnikov i knizhnosti Drevnei Rusi. P. I (11th - 1st half of the 14th cent.). Leningrad, 1987, pp. 423-425.

Slovar' drevnerusskogo yazyka XI-XIV vv. Moscow, 1988-. Vol. 1-.

Slovar' russkogo yazyka XI-XVII vv. Moscow, 1975-. Vol. 1-.

Sobolevskiy A. I. Materialy $i$ issledovaniya $v$ oblasti slavyanskoy filologii $i$ arkheologii. St.-Petersburg, 1910.

Sukhomlinov M. I. Rukopisi grafa A. S. Uvarova. Vol. 2. St.-Petersburg, 1858.

Temchin S. Yu. Tolkovye prazdnichnye kanony - neuchtennoe drevnerusskoe proizvedenie domongol'skogo perioda. Vostochnaya Evropa $v$ drevnosti i srednevekov'ye. Antichnye i srednevekovye obshchnosti. XXIX Chteniya pamyati chlena-korrespondenta AN SSSR Vladimira Terent'yevicha Pashuto. Moskva, 19-21 aprelya 2017 g. Materialy konferentsii. Moscow, 2017, pp. 223-228. (In Russ.)

Tvorogov O. V. Perevodnye zhitiya v russkoi knizhnosti XI-XV vekov. Katalog. Moscow-St.-Petersburg, 2008.

Undol'skiy V. M. Slavyano-russkie rukopisi V. M. Undol'skogo, opisannye samim sostavitelem i byvshim vladel'tsem sobraniya, No. 1-579. Moscow, 1870.

Usener 1886 - Usener H. (ed.) Acta S. Marinae et S. Christophori. Festschrift zur fünften Säcularfeier der Carl-Ruprechts-Universität zu Heidelberg. Bonnae, 1886, S. 15-46. 
Vershinin K. V. Slavyanskiiperevod neizvestnoi kateny na Psaltyr'. Drevnyaya Rus'. Voprosy medievistiki. 2017, no. 3 (69), pp. 23-24. (In Russ.)

Vinogradov V. P. Ustavnye chteniya. Sergiev Posad, 1915, no. 3.

Yukhimenko E. M. Traditsiya sostavleniya Chetiikh Minei v staroobryadcheskoi srede. Slavia Orientalis. Vol. 62. 2013, № 1, pp. 87-97. (In Russ.)

Zaimov I., Kapaldo M. Suprasl'skii, ili Retkov sbornik. Vol. 2. Sofiya, 1983.

Zaliznyak A. A. Drevnerusskie enklitiki. Moscow, 2008.

Zavadskaya S. V. K voprosu o «stareishinakh» v drevnerusskikh istochnikakh XI-XIII vv. Drevneishie gosudarstva na territorii SSSR. Materialy i issledovaniya, $1987 \mathrm{~g}$. Moscow, 1989, pp. 36-42. (In Russ.) 